\title{
ANALISIS PENGARUH BUDAYA ORGANISASI TERHADAP EFEKTIFITAS INTEGRATED ACADEMIC INFORMATION SYSTEM (IRAISE) UIN SUSKA RIAU
}

\author{
${ }^{1}$ Syaifullah,SE., M.Sc ${ }^{2}$ Ozi Saputra, ${ }^{3}$ Hasdi radiles, ST., MT \\ ${ }^{1,2,3}$ Program Studi Sistem Informasi, Fakultas Sains dan Teknologi UIN Suska Riau \\ Jl. HR Soebrantas KM.18 Panam Pekanbaru - Riau \\ Email: ${ }^{1}$ dir_mpun@yahoo.com, ${ }^{2}$ ozi.saputra@ students.uin-suska.ac.id, \\ ${ }^{3}$ hasdi99@gmail.com
}

\begin{abstract}
ABSTRAK
Budaya Organisasi merupakan suatu perekat sosial yang ada dalam organisasi, mengandung nilai, kebiasaan serta kepercayaan. Organisasi memiliki dampak secara langsung terhadap teknologi informasi melalui budaya organisasi. Saat ini di UIN SUSKA Riau sudah mengaplikasikan sebuah sistem informasi berbasis web yang dibangun untuk perorganisasian akademik untuk mempermudah pekerjaan. Namun walaupun sudah dibangun aplikasi berbasis web masih ada yang lalai. Oleh karena itu perlu diketahui budaya Mahasiswa yang menyebabkan kelalaian. Budaya tersebut akan digunakan sebagai pengukur efektifitas terhadap sistem informasi. Pada penelitian ini dilakukan penerapan Organiztional Culture Assesment Instrument serta Delone dan Mclean untuk budaya mahasiswa terhadap efektifitas. Dari hasil perhitungan budaya mahasiswa saat ini menggunakan tools Excel didapat hasil yaitu Clan yang menekankan kepada focus kerja sama tim, komitmen dan bersifat kekeluargaan sebesar 25.61 dan untuk diharapkan tetap budaya Clan sebesar 27.10. Hasil perhitungan di tolls SmartPLS 3 dari perhitungan budaya dan efektifitas menyatakan bahwa budaya organisasi tidak berpengaruh terhadap efektifitas sistem informasi iRaise kerena budaya Clan lebih memfokuskan pada kinerja tim, komitmen dan bersifat kekeluargaan kerena hal itu apabila salah satu anggota tim berhalangan maka pekerjaan tidak bisa diteruskan dan hal itu menyebabkan produktifitas yang kurang baik dan membuat pekeraan menjadi terlambat.

Kata kunci: Budaya Organisasi, Delone dan Mclean, Efektifitas, ,Organiztional Culture Assesment Instrument, Smart PLS 3.
\end{abstract}

\section{A. PENDAHULUAN}

Budaya Organisasi merupakan suatu perekat sosial yang ada dalam organisasi, mengandung nilai, kebiasaan serta kepercayaan [1]. Organisasi maupun perusahaan tidak akan lepas dari manajemen sumber daya manusia. Dimana setiap nilai dan kebiasaan mereka membentuk sebuah budaya organisasi. Kemampuan suatu organisasi dalam mengimplementasikan nilai-nilai budaya organisasinya dapat mendukung organisasi tersebut tumbuh dan berkembang secara berkelanjutan. Sehingga budaya organisasi berperan penting sebagai corporate value dalam bertindak dan menyelesaikan berbagai persoalan, serta mendukung terwujudnya visi dan misi organisasi [2]. Organisasi mempunyai dampak langsung terhadap teknologi informasi melalui budaya organisasi yaitu, keputusan tentang bagaimana teknologi akan digunakan dan peran apa yang dimainkan dalam organisasi. Hal ini menunjukkan adanya keterkaitan antara budaya organisasi dan sistem informasi yang sedang berjalan.

Sistem Informasi didefinisikan sebagai satuan komponen yang saling terhubung yang memproses, menyimpan, dan mendistribusikan informasi untuk mendukung pengambilan keputusan dan kendali dalam suatu organisasi[3]. Organisasi memiliki dampak secara langsung terhadap tehnologi informasi melalui budaya organisasi [4]. Selain itu peningkatan sumber daya diinvestasikan dalam infrastruktur sistem informasi pada organisasi yang memberikan pelayanan dan sebagai enabler dalam menghasilkan nilai dan melaksanakan tatakelola yang lebih baik [5]. Universitas Islam Sultan Syarif Kasim Riau (UIN SUSKA) Riau sudah mengaplikasikan sebuah sistem informasi berbasis web yang dibangun dengan tujuan untuk pengorganisasian data akademik secara online yaitu iRaise.

Jumlah pengguna iRaise di UIN SUSKA Riau saat ini berjumlah 25.358 mahasiswa aktif [6]. Namun belum diketahui seperti apakah budaya mahasiswa terhadap penggunaan sistem informasi iRaise dan budaya dominan apa yang sedang berjalan di UIN SUSKA Riau. Selain itu belum pernah dilakukan juga analisis apakah budaya tersebut berpengaruh terhadap tingkat efektifitas sistem informasi iRaise. Untuk mendukung data penelitian, peneliti melakukan studi pendahuluan mengenai budaya mahasiswa terhadap pengguanan iRaise dengan mengajukan beberapa pertanyaan kepada 50 mahasiswa aktif yang diwakili dari setiap fakultas sebagai sampel dari populasi per fakultas. Dari studi pendahuluan tersebut dapat dilihat gambaran mengenai budaya mahasiswa terhadap penggunaan sistem informasi iRaise sebagai berikut: 
1) Mahasiswa cenderung mengisi KRS pada tahap deadline dengan pesentase sebesar $77,08 \%$, yang menunjukan adanya kebiasaan mahasiswa yang mengisi KRS di Iraise pada akhir priode. 2) Kecenderungan mahasiswa melakukan bimbingan KRS manual dengan dosen Penasehat Akademik (PA) masih kurang, ditunjukan dengan persentase sebesar $54,17 \%$ dan yang tidak melakukan bimbingan KRS manual sebesar 45,83\%. Hal ini bertentangan dengan peraturan yang mewajibkan mahasiswa untuk melakukan bimbingan KRS manual sebelum pengisian KRS online. 3) Kecenderungan mahasiswa masih sulit login ke Iraise dengan persentase 87,50. Hal ini meunjukan Iraise yang masih belum user friendly, namun mahasiswa diwajibkan mengunakan Iraise untuk proses akademik. 4) Kecenderungan mahasiswa melakukan perebutan kelas/ jadwal kuliah dengan persentase sebesar $72,92 \%$. Hal ini menunjukan mahasiswa masih tidak tertib dengan ketentuan atau prosedur Iraise yang melarang untuk pindah atau lompat lokal hingga penentuan dosen mata kuliah.

Robert Lamb dan Rob King [7] yang berjudul "Reconceptualizing User and Social Actors in Information System Research" mengatakan bahwa manusia memeberikan konstribusi yang signifikan terhadap optimalisasi pemanfaatan sistem informasi. Dengan kata lain pemanfaatan sistem informasi yang efektif sangat dipengaruhi oleh budaya organisasi yang berasal dari tradisi dan kebiasaan individual didalamnya. Cholid Fauzy [8] dengan judul "Pengaruh Budaya Organisasi Terhadap Efektivitas Sistem Informasi" menyatakan bahwa faktor-faktor dari budaya memberi pengaruh efektifitas sistem informasi walaupun tidak signifikan. Selain itu berdasarkan hasil evaluasi, pengaruh budaya terhadap sistem informasi juga memiliki hubungan terhadap kinerja. Faktor-faktor yang secara signifikan mempengaruhi efektifitas sistem informasi dalam penelitiannya adalah information quality, service quality, system quality, use, dan user satisfaction. Selanjutnya penelitian Murahartawaty [9] dengan judul "Analisis Pengaruh Budaya Organisai Terhadap Efektivitas Implementasi Sistem Informasi" yang dilakukan pada Perguruan Tinggi XYZ di Bandung. Hasil penelitiannya menunjukkan budaya market dan adhokrasi bersifat sebagai kelemahan (liabilities) dalam mencapai efektifitas implementasi sistem informasi serta budaya klan dan hirarki bersifat sebagai kekuatan (asset) untuk mencapai efektifitas implementasi sistem informasi di perguruan tinggi XYZ.

Berdasarkan penjelasan tersebut, peneliti akan melakukan analisis faktor-faktor budaya yang berpengaruh secara signifikan terhadap efektifitas sistem informasi iRaise UIN SUSKA Riau. Dari penelitian ini akan diperoleh budaya organisasi dominan yang sedang berjalan dan yang diharapkan serta model pengaruh budaya terhadap efektifitas sistem informasi di UIN SUSKA Riau. Hasil penelitian ini dapat digunakan UIN SUSKA Riau untuk meningkatkan efektifitas dan mengoptimalkan penggunaan sistem informasi serta sebagai pengambilan keputusan apakah budaya organisasi yang berjalan perlu diubah atau dipertahankan.

\section{B. LANDASAN TEORI}

\section{B.1. Budaya Organisasi}

Budaya Organisasi merupakan nilai-nilai dominan atau kebiasaan dalam suatu organisasi perusahaan yang disebarluaskan dan sebagai filosofi kerja karyawan. Menurut Hofstede [10] budaya organisasi merupakan pola pemikiran, perasaan dan tindakan dari suatu kelompok sosial, yang membedakan dengan kelompok sosial yang lain. Hal penting yang perlu ada dalam definisi budaya organisasi adalah suatu sistem nilai yang dirasakan maknanya oleh seluruh individu dalam perusahaan dan meyakini sistem nilai tersebut sebagai landasan gerak perusahaan. Gibson [5] mendefinisikan budaya organisasi sebagai suatu sistem nilai-nilai, keyakinan dan norma-norma yang unik, dimiliki secara bersama oleh anggota suatu organisasi.

Ada empat tipe budaya yang dikembangkan oleh Cameron dan Quinn yaitu sebagai berikut [11]:
1. Budaya Clan
2. Budaya Adhocracy
3. Budaya Market
4. Budaya Hierarchy

\section{B.2. Culture Value Framwork (CVF)}

Model ini merupakan salah satu model yang cukup komprehensif dalam menjelaskan relasi kultur terhadap berbagai aspek organisasi. Model ini memperlihatkan secara terperinci bahwa setiap tipe kultur memiliki kecenderungan yang berbeda dalam sejumlah variabel organisasi yang dipengaruhinya.

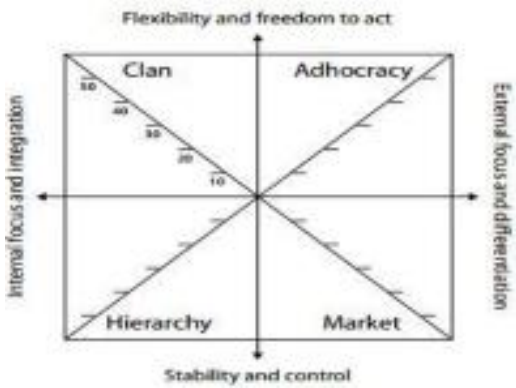

Cameron dan Quinn menjelaskan 4 kuadran, sesuai dengan 4 budaya organisasi yang memiliki perbedaan yang sangat kuat. Pada sumbu horizontal ada fokus internal dan integrasi vs fokus eksternal dan diferensiasi. Pada sumbu yang mengarah ke kiri menunjukkan bahwa organisasi fokus internal (apa yang penting untuk perusahaan, bagaimana kita menginginkan untuk bekerja) sedangkan sumbu yang mengarah ke kanan menunjukkan bahwa 
organisasi fokus eksternal (apa yang penting untuk dunia luar, klien, dan pasar). Pada sumbu vertikal terdapat stabilitas dan kontrol vs fleksibilitas dan keleluasaan. Pada sumbu yang mengarah ke atas menunjukkan bahwa organisasi memiliki hasrat untuk membuat semuanya fleksibel dan leluasa, sedangkan sumbu yang mengarah ke bawah menunjukkan bahwa organisasi meninginkan nilai yang berlawanan, yaitu stabilitas dan kontrol [12].

\section{B.3. Organizatioanl Culture Assesment Instrument (OCAI)}

OCAI dikembangkan oleh Kim Cameron dan Robert Quinn merupakan metode penelitian untuk menilai budaya organisasi [11].OCAI merupakan pengembangan dari Competing Values Framework (CVF), sangat berguna dalam mencerminkan ke arah mana perusahaan ini dikelompokkan berdasarkan kulturnya seperti yang sudah dijelaskan pada gambar sebelumnya yaitu budaya clan, adhocracy, market, atau hierarchy untuk mendukung misi dan tujuannya, dan juga untuk dapat mengidentifikasi elemen-elemen di dalam kultur yang dapat melawan misi dan tujuan [13].

Kusdi [14] menjelaskan enam dimensi budaya, yang dapat digunakan untuk melihat profil budaya perusahaan, yaitu:

1. Karateristik Dominan

2. Kepemimpinan Organisasi

3. Pengelolaan Karyawan

4. Perekat Organisasi

5. Penekanan Strategis

6. Kriteria Keberhasilan

Instrumen OCAI ini berbentuk sebuah kuesioner yang memerlukan tanggapan dari responden. Pengukuran OCAI dibuat berdasarkan skala yang disebut ipsative rating scale, dimana individu diminta membagi nilai 100 untuk empat alternatif jawaban pada setiap dimensi kultur. Karakteristik atau dimensi budaya OCAI tersebut di muat dalam kuisioner yang mengandung pernyataan sesuai dimensi budaya. Setiap dimensi mengandung empat tipe budaya clan, adhokracy, market, dan hirarky dengan dua penilaian budaya sekarang dan budaya yang diharapkan. Tujuan OCAI adalah untuk menilai enam dimensi kunci budaya organisasi yang dikaitkan oleh empat tipe budaya yang sudah dijelaskan [12].

\section{B.4. IS Succes Model Delone dan Mclean}

Model yang diusulkan ini merefleksi ketergantungan dari enam pengukuran kesuksesan sistem informasi. Keenam elemen atau faktor atau komponen atau pengukuran dari model ini adalah:

1. Kualitas system (system quality)

2. Kualitas informasi (information quality)

3. Penggunaan (use)

4. Kepuasan pemakai (user satisfaction)

5. Dampak individual (individual impact)
6. Dampak

impact)

organisasional (organizational

Model kesuksesan ini didasarkan pada proses dan hubungan kausal dari dimensi-dimensi di model. Model ini tidak mengukur ke enam dimensi pengukuran kesuksesan sistem informasi secara independen tetapi mengukurnya secara keseluruhan satu mempengaruhi yang lainnya. Berikut Model Delone dan McLine [15]:

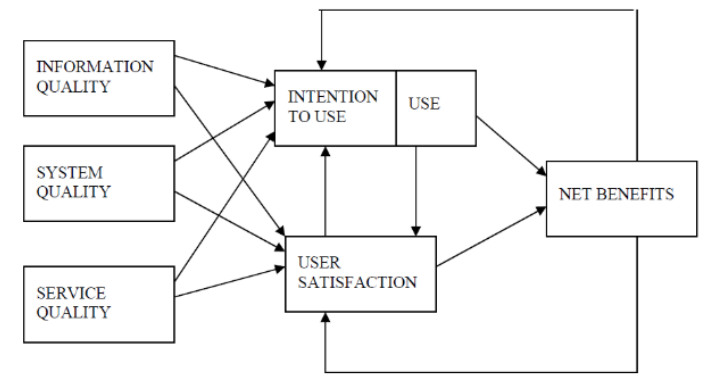

Gambar 2. Update Model DeLone dan McLean (2003)

\section{METODOLOGI PENELITIAN}

Metodologi penelitian ini di adopsi dari kerangka berpikir Hevner dkk [16] mengenai metodologi IS Research yang telah dimodifikasi mengikuti penelitian cholid [8]. Metodologi penelitian ini terbagi dalam dua sisi yaitu relevanve (sesuai dengan fakta dilapangan) seperti, wawancara, observasi, kuisioner dan Rigor (pengetahuan) antara lain studi literatur, penelitian terdahulu. Adapun langkah-langkah yang ditempuh dalam penelitian ini adalah sebagai berikut:

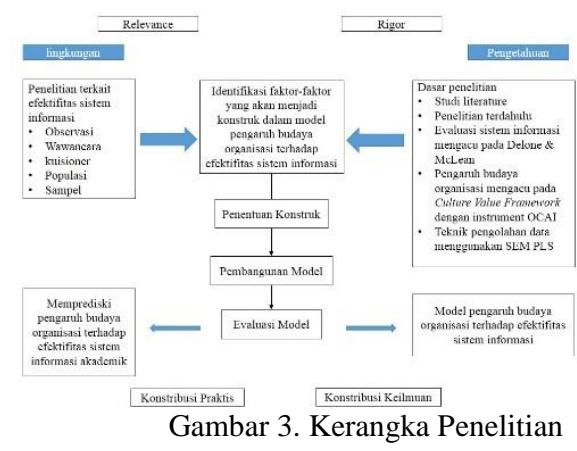

\section{C.1. Tahap 1 Identifikasi Faktor Pengaruh Budaya}

Dalam melakukan penelitian, terlebih dahulu di tentukan faktor-faktor apa saja yang dapat mempengaruhi berhasilnya penelitian yang dilakukan. Faktor-faktor yang mempengaruhi jalannya penelitian di gambarkan dalam kerangka penelitian yang di dalamnya.

\section{C.2. Tahap 2 Penelitian Terkait Keberhasilan Sistem Informasi}

Pada tahap ini peneliti melakukan analisis terhadap lingkungan UIN SUSKA Riau untuk mengembangkan solusi berbasis teknologi untuk masalah bisnis yang penting dan relevan sehingga 
mendapatkan data-data pendukung terkait permasalahan efektifitas sistem informasi. Datadata pendukung untuk penelitian terkait tersebut didapatkan dari hasil studi pendahuluan, wawancara, observasi, menyebarkan kuisioner, melalui penelitian langsung kepada, yaitu mahasiswa S1 mahasiswa UIN SUSKA Riau, organisasi dan teknologi yang digunakan oleh UIN SUSKA Riau. Dalam penelitian ini penulis menggunakan beberapa metode atau pendekatan untuk mengumpulkan data

\section{C.3. Tahap 3 Observasi}

Observasi dilakukan di UIN SUSKA Riau yang bertujuan untuk mendapatkan data permasalahan yang ada di UIN SUSKA Riau. Dari hasil observasi diperoleh sebuah penelitian dengan judul, "Pengaruh Budaya Organisasi Terhadap Efektifitas Integrated Academic Information System (IRASE) UIN SUSKA Riau". Dari observasi tersebut dapat dilihat gambaran mengenai budaya mahasiswa terhadap penggunaan sistem informasi iRaise sebagai berikut: 1) Mahasiswa cenderung mengisi KRS pada tahap deadline dengan pesentase sebesar 77,08\%, yang menunjukan adanya kebiasaan mahasiswa yang mengisi KRS di Iraise pada akhir priode. 2) Kecenderungan mahasiswa melakukan bimbingan KRS manual dengan dosen Penasehat Akademik (PA) masih kurang, ditunjukan dengan persentase sebesar $54,17 \%$ dan yang tidak melakukan bimbingan KRS manual sebesar $45,83 \%$. Hal ini bertentangan dengan peraturan yang mewajibkan mahasiswa untuk melakukan bimbingan KRS manual sebelum pengisian KRS online. 3) Kecenderungan mahasiswa masih sulit login ke Iraise dengan persentase 87,50. Hal ini meunjukan Iraise yang masih belum user friendly, namun mahasiswa diwajibkan mengunakan Iraise untuk proses akademik. 4) Kecenderungan mahasiswa melakukan perebutan kelas/ jadwal kuliah dengan persentase sebesar $72,92 \%$. Hal ini menunjukan mahasiswa masih tidak tertib dengan ketentuan atau prosedur Iraise yang melarang untuk pindah atau lompat lokal hingga penentuan dosen mata

kuliah.

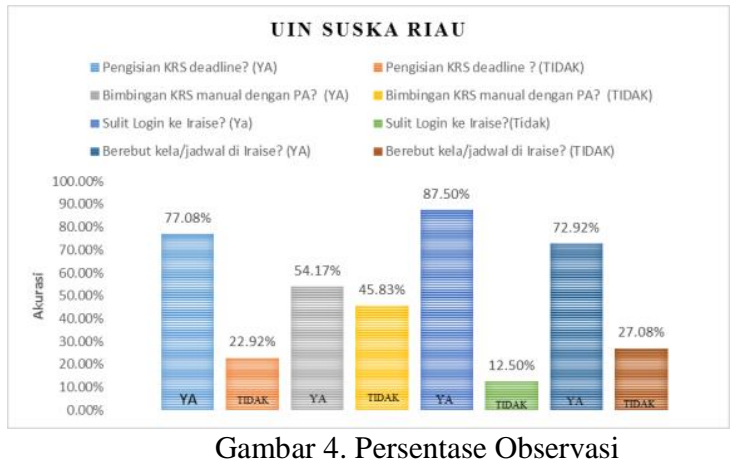

\section{C.4. Tahap 4 Wawancara}

Melakukan tatap muka langsung untuk mendapatkan informasi-informasi mengenai sistem informasi iRaise dengan mengajukan pertanyaanpertanyaan mengenai gambaran sistem informasi iRaise yang berjalan saat ini kepada mahasiswa S1 UIN SUSKA Riau selaku pengguna iRaise.

\section{C.5. Tahap 5 Populasi}

Populasi adaah wilayah generalisasi yang terdiri atas: obyek/subyek yang mempunyai kualitas dan karakteristik tertentu yang ditetapkan oleh peneliti untuk dipelajari dan kemudian ditarik kesimpulannya [17].

Tabel 1. Jumlah Populasi

\begin{tabular}{|c|c|c|}
\hline No & Nama Populasi & Jumlah \\
\hline 1 & Fakultas Tarbiyah dan Keguruan & 6.884 \\
\hline 2 & $\begin{array}{llll}\begin{array}{l}\text { Fakultas } \\
\text { Hukum }\end{array} & \text { Syari'ah } & \text { dan } & \text { Ilmu } \\
\end{array}$ & 4.121 \\
\hline 3 & Fakultas Ushuluddin & 574 \\
\hline 4 & $\begin{array}{llll}\text { Fakultas } & \text { Dakwah dan } & \text { Ilmu } \\
\text { Hukum } & & & \\
\end{array}$ & 2.158 \\
\hline 5 & Fakultas Sains dan Teknologi & 4.338 \\
\hline 6 & Fakultas Psikologi & 1.375 \\
\hline 7 & Fakultas Ekonomi dan Ilmu Sosial & 4.589 \\
\hline 8 & Fakultas Pertanian dan Peternakan & 1.499 \\
\hline \multicolumn{2}{|r|}{ Total } & 25.538 \\
\hline
\end{tabular}

Dari pada tabel 1 dapat dilihat bahwa Fakultas Tarbiyah dan Keguruan mempunyai 6.884 mahasiswa, Fakultas Syari'ah dan Ilmu Hukum 4.121 mahasiswa, Fakultas Ushuluddin 574 mahasiswa, Fakultas Dakwah dan Ilmu Hukum 2.158 mahasiswa, Fakultas Sains dan Teknologi 4.338 mahasiswa, Fakultas Psikologi 1.375 mahasiswa, Fakultas Ekonomi dan Ilmu Sosial 4.589 mahasiswa, Fakultas Pertanian dan Peternakan 1.499 mahasiswa, yang mana total jumlah keseluruhan sebanyak 25.538 mahasiswa.

\section{C.6. Tahap 6 Sampel}

Sampel adalah sebagian dari subyek dalam populasi yang diteliti, yang sudah tentu mampu secara representative dapat mewakili populasinya [18]. Sampel untuk ini diambil dari jumlah populasi mahasisa UIN SUSKA Riau sebanyak 25.538. Penentuan jumlah sampel didapatkan menggunakan rumus slovin.

$$
n=\frac{25.538}{\begin{array}{c}
25.538 \cdot(0,10)^{2}+1 \\
n=99,60
\end{array}}
$$

Setelah melakukan perhitungan menggunakan rumus slovin di dapatkan hasil 99,60, maka jumlah tersebut digunakan untuk sampel dalam penelitian 
ini. Hasil tersebut dijelaskan dalam bentuk tabulasi sebagai berikut:

Tabel 2. Total Sampel

\begin{tabular}{|c|l|c|}
\hline No & \multicolumn{1}{|c|}{ Nama Sampel } & Jumlah \\
\hline 1 & Fakultas Tarbiyah dan Keguruan & 14 \\
\hline 2 & Fakultas Syari'ah dan Ilmu Hukum & 12 \\
\hline 3 & Fakultas Ushuluddin & 12 \\
\hline 4 & Fakultas Dakwah dan Ilmu Hukum & 12 \\
\hline 5 & Fakultas Sains dan Teknologi & 14 \\
\hline 6 & Fakultas Psikologi & 12 \\
\hline 7 & Fakultas Ekonomi dan Ilmu Sosial & 12 \\
\hline 8 & Fakultas Pertanian dan Peternakan & 12 \\
\hline & Total & $\mathbf{1 0 0}$ \\
\hline
\end{tabular}

\section{C.7. Tahap 7 Kuisioner}

Menyebarkan kuisioner yang berisi pernyataan-peryataan tertulis untuk diisi oleh sumber informasi, kuisioner di sebarkan dengan jumlah yang terbatas berdasarkan sampel yang telah ditentukan yaitu sebanyak 100 orang. Selanjutnya kuisioner disebar kepada sumber informasi kemudian hasil dari kuisioner yang telah disebar akan menghasilkan data untuk diolah menggunakan Smart PLS.

Kuisioner dibagi menjadi dua dimensi yaitu: efektifitas dan budaya organisasi. Instrumen kuisioner untuk mengukur efektifitas penerapan sistem menggunkan Model Delone \& Mclean dengan 6 instrumen. Sementara itu untuk budaya organisasi menggunakan kerangka CVF dengan instrumen 4 dimensi budaya organisasi OCAI.

\section{C.8. Tahap 8 Dasar Penelitian}

Tahapan ini dalam penelitian hevner [16] disebut sebagai tahapan Desain-ilmu pengetahuan. Metode pengumpulan data, referensi dan informasi dengan cara menggali ilmu pengetahuan yang diperoleh dari sumber-sumber buku, karya tulis, jurnal ilmiah, makalah dan sumber lainnya yang berhubungan dengan subjek penelitian. Desain-ilmu penelitian harus menghasilkan artefak yang layak dalam bentuk konstruk, model, metode, atau instantiasi yang berkaitan dengan permasalahan di perusahaan.

\section{C.9. Studi Literatur}

Studi literatur merupakan gambaran menyeluruh tentang apa yang sudah dikerjakan dan bagaimana proses mengerjakannya. Menurut Danial dan Warsiah Studi literatur merupakan penelitian yang dilakukan oleh peneliti dengan mengumpulkan sejumlah buku-buku yang berkaitan dengan masalah dan tujuan penelitian [19]. Secara umum studi literatur adalah cara untuk menyelesaikan persoalan dengan mencari sumber-sumber dari penelitian sebelumnya dengan kata lain disebut dengan studi pustaka. Adapun beberapa sumber sebagai berikut: 1) Geer Hofstede, Cultural Dimensions In Management and Planning, 1984. 2) Hevner, Design Science In Information Systems Research 2004, 3) Putro, Kultur Organisasi Menggunakan Hofstede dan OCAI Terhadap Strategi Penerapan Teknologi Informasi, 2010. 4) Heru Nugroho, Analisis Budaya Organisasi Sebagai Faktor Kontigensi Dalam Penerapa Tatakelola TI di Politeknik Telkom, 2013. 5) Murahartawaty, Analisis Pengaruh Budaya Organisasi Terhadap Efektifitas Implementasi Sistem Informasi, 2013. 6) Erik et all, Rekomendasi Sistem Informasi Berdasarkan Budaya Organisasi Menggunakan Metode Organizational Culture Assessment Instrument dan Computing Values Framework, 2014. 7) Cholid, Pengaruh Budaya Organisasi Terhadap Efektifitas Sistem Informasi, 2015. 8) Megawati at all, Analisis Budaya Organisasi Teknologi Informasi Menggunakan OCAI, 2015. 9) Megawati at all, Evaluasi Budaya Organisasi dalam Penerapan Teknologi Informasi Menggunakan Organizational Culture Assessment Instrument (OCAI), 2015. 10) E-book Culture Organizational 2018. 11) E-book OCAI, 2018.

\section{C.10. Tahap 10 Penelitian Terdahulu}

Penelitian terdahulu menjadi salah satu acuan penulis dalam melakukan penelitian sehingga dapat memperbanyak teori yang digunakan dalam mengkaji penelitian yang dilakukan. Beberapa penelitan terdahulu yang menjadi acuan dalam penelitian adalah penelitian dari Hevner [16], Penelitian Cholid Fauzi [8], dan Penelitian oleh Murahartawati [9].

\section{C.11. Tahap 11 Evaluasi SI}

Pada tahap ini penulis melakukan kajian yang berhubungan dengan teori-teori yang akan digunakan dalam melakukan penelitian. Kajian teori ini diperoleh dari jurnal utama, jurnal pendukung, dan ebook online sebagai dasar dan acuan penelitian.

Output dari tahap 2 dan 6 adalah dapat di identifikasi faktor-faktor yang akan menjadi konstruk dalam model pengaruh budaya organisasi terhadap efektifitas sistem informasi pada UIN SUSKA Riau.

\section{C.12. Tahap 12 Teknik Pengolahan Data}

Analisis PLS adalah teknik statistika multivariat yang melakukan pembandingan antara variabel dependen berganda dan variabel independen berganda. PLS salah satu metode statistika SEM berbasis varian yang didesain untuk menyelesaikan regresi berganda ketika terjadi permasalahan spesifik pada data, seperti ukuran sampel penelitian kecil, adanya data yang hilang (missing values) dan multikolinearitas antar 
prediktor sehingga meningkatkan standart error dari koefesien yang diestimasi [20].

\section{C.13. Tahap 13 Penentuan Konstruk}

Konstruk merupakan jenis konsep tertentu yang berada dalam tingkatan abstraksi yang lebih tinggi dari konsep dan diciptkan untuk tujuan teoritis tertentu. Konstruk dapat diartikan sebagai konsep yang telah dibatasi pengertiannya sehingga dapat diamati dan diukur [20].

Tabel 3. Daftar Konstruk Budaya dan Efektifitas

\begin{tabular}{|c|c|}
\hline Konstruk & Definisi \\
\hline $\begin{array}{l}\text { Information } \\
\text { Quality } \\
\text { (IQ) }\end{array}$ & $\begin{array}{l}\text { Persepsi pengaruh kualitaas informasi } \\
\text { terhadap penggunaan dan kepuasan } \\
\text { SI dengan indikator, understandbility, } \\
\text { reliability, usefullness }\end{array}$ \\
\hline $\begin{array}{l}\text { System } \\
\text { Quality } \\
\text { (SQ) }\end{array}$ & $\begin{array}{l}\text { Persepsi pengaruh kualitaas informasi } \\
\text { terhadap penggunaan dan kepuasan } \\
\text { SI dengan indikator, access, usability, } \\
\text { navigation, interactivity }\end{array}$ \\
\hline $\begin{array}{l}\text { Service } \\
\text { Quality } \\
\text { (SEQ) }\end{array}$ & $\begin{array}{l}\text { Persepsi pengaruh kualitaas layanan } \\
\text { terhadap penggunaan dan kepuasan } \\
\text { SI dengan indikator, responsiveness, } \\
\text { emphaty, assurance }\end{array}$ \\
\hline Use & $\begin{array}{l}\text { Persepsi pengaruh kualitaas sistem, } \\
\text { layanan, dan informasi terhadap } \\
\text { manfaat SI dengan indikator } \\
\text { frequency of use dan intensity }\end{array}$ \\
\hline $\begin{array}{l}\text { User } \\
\text { Satisfaction }\end{array}$ & $\begin{array}{l}\text { Persepsi pengaruh kualitaas sistem, } \\
\text { layanan, dan informasi terhadap } \\
\text { manfaat SI dengan indikator, content, } \\
\text { acuracy, format, ease of use dan } \\
\text { timeliness }\end{array}$ \\
\hline $\begin{array}{l}\text { Efektifitass } \\
\text { (EFEK) }\end{array}$ & $\begin{array}{l}\text { Persepsi pengaruh dari penggunaan } \\
\text { dan kepuasan terhadap kinerja SI } \\
\text { dengan indikator task } \\
\text { performance,eficience, dan } \\
\text { productivity }\end{array}$ \\
\hline $\begin{array}{l}\text { Budaya } \\
\text { Clan }\end{array}$ & $\begin{array}{l}\text { Persepsi pengaruh budaya organisasi } \\
\text { Clan yang dominan dalam efektifitas } \\
\text { penggunaan, kepuasaan,dan manfaat } \\
\text { informasi }\end{array}$ \\
\hline $\begin{array}{l}\text { Budaya } \\
\text { Adhocrasi }\end{array}$ & $\begin{array}{l}\text { Persepsi pengaruh budaya organisasi } \\
\text { Adhocrasi yang dominan dalam } \\
\text { efektifitas penggunaan, } \\
\text { kepuasaan,dan manfaat informasi }\end{array}$ \\
\hline $\begin{array}{l}\text { Budaya } \\
\text { Market }\end{array}$ & $\begin{array}{l}\text { Persepsi pengaruh budaya organisasi } \\
\text { Market yang dominan dalam } \\
\text { efektifitas penggunaan, } \\
\text { kepuasaan,dan manfaat informasi }\end{array}$ \\
\hline $\begin{array}{l}\text { Budaya } \\
\text { Hiraki }\end{array}$ & $\begin{array}{l}\text { Persepsi pengaruh budaya organisasi } \\
\text { Hiraki yang dominan dalam } \\
\text { efektifitas penggunaan, } \\
\text { kepuasaan,dan manfaat informasi }\end{array}$ \\
\hline
\end{tabular}

\section{C.14. Tahap 14 Pembangunan Model Penelitian}

Model penelitian ini di bangun dengan menggabungkan dua model yaitu, IS Succes Model dan CVF untuk mengetahui pengaruh antara budaya organisasi dan efektivitas sistem informasi di UIN SUSKA Riau.

Gambar 5. Model yang diajukan

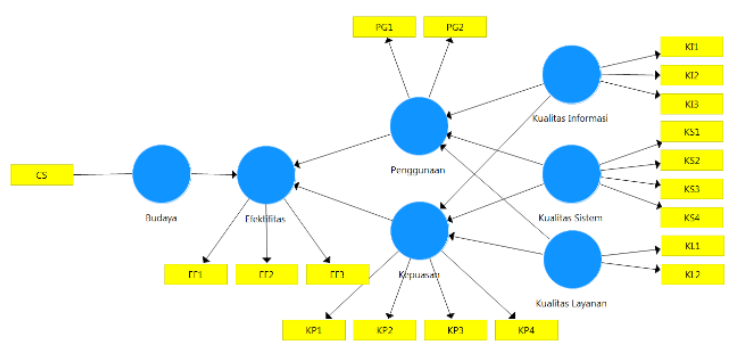

C.15. Tahap 15 Evaluasi Model

Kegiatan mengevaluasi model adalah dengan cara mengolah Data Responden dan Kuisioner. Kegiatan yang dilakukan disini yang dilakukan adalah menginputkan data yang ada pada kuisioner yang telah disebar, yaitu deskripsi tanggapan responden terhadap seluruh pertanyaan. Kegiatan ini dilakukan setelah melakukan kegiatan penyebaran kuisioner.

Tahap ini merupakan tahap awal dalam melakukan analisis, dimana pada tahap ini peneliti menentukan bentuk dari model penelitian. Pada penelitian ini variabel-variabel laten atau konstruk yang diteliti adalah human, organization, and technology dengan sub konstruknya adalah pengguna sistem, kepuasan pengguna, struktur organisasi, lingkungan organisasi, kualitas sistem, kualitas layanan, penggunaan iRaise. Dari konstrukkonstruk tersebut akan memudahkan peneliti dalam melakukan penelitian kerena dengan sudah ditentukannya kontruk-konstruk tersebut maka, penelitian yang akan dilakukan akan lebih terarah. Analisis yang dilakukan pada tahap ini menggunakan SEM-PLS [21].

\section{C.16. Tahap 16 Hasil Penelitian}

Terdapat dua kelompok dari hasil penelitian ini, yaitu:

1. konstribusi keilmuan

Output akhir penelitian ini sebagai konstribusi keilmuan adalah Model pengaruh budaya organisasi terhadap efektifitas sistem informasi.

2. Konstribusi Praktis

Output akhir penelitian ini sebagai konstribusi Praktis adalah Memprediksi Pengaruh Budaya Terhadap Efektifitas Sistem Informasi.

\section{ANALISIS DAN PEMBAHASAN}

D.1. Analisa Sistem yang Sedang Berjalan UIN SUSKA Riau merupakan suatu perguruan tinggi negeri yang berada di Pekanbaru. UIN SUSKA Riau telah menggunakan sistem informasi 
iRase sejak tahun 2015. Yang menggunakan iRase yaitu seluruh mahasiswa UIN SUSKA Riau beserta Dosen dan Karyawan. UIN SUSKA Riau terdapat beberapa Fakultas untuk S1 diantaranya yaitu Fakultas Syariah dan Ilmu Hukum, Fakultas Usuluddin, Fakultas Pesikilogi, Fakultas Fapertapet, Fakultas Ekonomi dan Ilmu Sosial, Fakultas Sains dan Teknologi, Fakultas Dakwah dan Komunikasi, dan Terakhir Fakultas Tarbiyah. Dan di UIN SUSKA Riau juga ada S2 dan S3 yang menggunakan iRase. Layanan yang terdapat di iRaise ini mulai dari pengisian KRS, Pengajuan Cuti Kuliah, Kartu Hasil Studi (KHS), Pendaftaran Wisuda Online, Kelas Elektronik, jadwal, hingga dapat melihat story pembayaran uang kuliah. Akan terapi belum diketahui bagaimana bidaya organisasi yang sedang berjalan saat ini sehingga tidak diketahui bagaimana pengaruh budaya organisasi terhadap efektifitas sistem informasi.

\section{D.1.1. Integrated Academic Information System (IRAISE)}

Iraise di UIN SUSKA Riau adalah sistem yang dapat diakses melalui jaringan internet yang berguna untuk mendukung proses akademik dengan menyediakan berbagai macam menu pilihan. Berikut gambaran Irase di UIN SUSKA Riau.

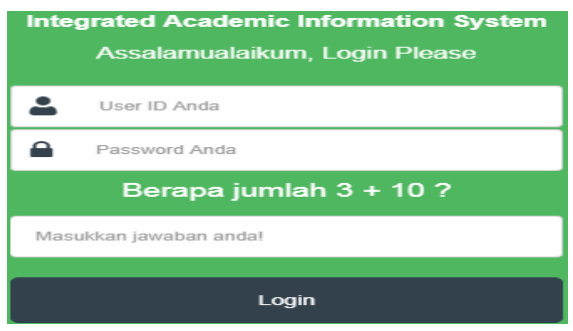

Gambar 6. Login Iriase

Gambar 6 diatas merupakan tampilan menu login pada iRaise yang biasa di akses oleh mahasiswa, pegawai dan dosen di UIN SUSKA Riau, dimana sebelum login harus memasukan User ID dan Password serta memasukan hasil perhitungan yang telah di tampilkan pada menu login.

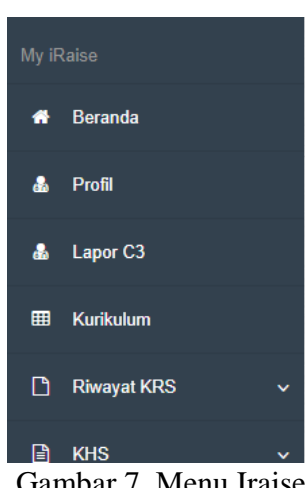

Gambar 4.2 diatas merupakan tampilan menu di iRaise setelah login ke sistem, yang mana menu tersebut bisa di akses sesuai dengan kebutuhan si pengguna. Contohnya menu riwayat KRS, disini akan mengetahui mata pelajaran apa saja yang telah diambil dari semester 1 sampai akhir dan juga bisa mengetahui siapa dosen pengajar dan ruangannya.

\section{D.2. Analisis Responden}

Penelitian ini merupakan penelitian yang ditujukan kepada pengguna iRaise. Responden penelitian ini adalah mahasiswa UIN SUSKA Riau yang berjumlah 100 orang.

Tabel 4. Total Kuisioner Kembali

\begin{tabular}{|l|c|}
\hline \multicolumn{1}{|c|}{ Keterangan } & \multicolumn{1}{|c|}{$\begin{array}{c}\text { Jumlah } \\
\text { Kuisioner }\end{array}$} \\
\hline Kuisioner yang disebar & 100 \\
\hline Kuisioner yang kembali & 77 \\
\hline $\begin{array}{l}\text { Kuisioner yang tidak } \\
\text { kembali }\end{array}$ & 23 \\
\hline Kuisioner yang bisa diolah & 77 \\
\hline
\end{tabular}

Berikut ini merupakan deskripsi umum karaktersitik sampel menurut jenis kelamin, semester, dan fakultas.

Tabel 5. Kuisioner Kembali Menerut Jenis Kelamin

\begin{tabular}{|c|c|}
\hline Jenis kelamin & Jumlah \\
\hline Laki-laki & 24 \\
\hline Perempuan & 53 \\
\hline
\end{tabular}

Tabel 6. Kuisioner kembali Menerut Semester

\begin{tabular}{|c|c|}
\hline Semester & Jumlah \\
\hline 14 & 8 \\
\hline 12 & 1 \\
\hline 10 & 2 \\
\hline 8 & 30 \\
\hline 6 & 8 \\
\hline 4 & 15 \\
\hline 2 & 13 \\
\hline
\end{tabular}

Tabel 7. Kuisioner Kembali Menurut Fakultas

\begin{tabular}{|l|c|}
\hline \multicolumn{3}{|c|}{ Fakultas } & Jumlah \\
\hline Fakultas Tarbiyah dan Keguruan & 10 \\
\hline $\begin{array}{l}\text { Fakultas Syari'ah dan Ilmu } \\
\text { Hukum }\end{array}$ & 10 \\
\hline Fakultas Ushuluddin & 5 \\
\hline $\begin{array}{l}\text { Fakultas Dakwah dan Ilmu } \\
\text { Hukum }\end{array}$ & 11 \\
\hline Fakultas Sains dan Teknologi & 10 \\
\hline Fakultas Psikologi dan Ilmu & 12 \\
\hline $\begin{array}{l}\text { Fakultas Ekonomi dan } \\
\text { Sosial }\end{array}$ & 12 \\
\hline $\begin{array}{l}\text { Fakultas } \\
\text { Peternakan }\end{array}$ \\
\hline
\end{tabular}

\section{D.3. Analisis Data}


Dalam pengukuran budaya organisasi di UIN SUSKA Riau ini, menggunakan kuisioner OCAI yang digunakan untuk mendiagnosa budaya organisasi dengan menggunakan kuisioner yang berisi 24 pertanyaan dalam enam dimensi. Penyelesaian pengukuran budaya organisasi dengan metode OCAI akan memberikan gambaran tentang cara budaya organisasi beroperasi dan tidak ada jawaban benar atau salah atas setiap pertanyaan. Setiap organisasi kemungkinan besar akan menghasilkan tanggapan yang berbeda. Oleh kerena itu, harus diusahakan jawaban yang akurat dalam menaggapi pertanyaan sehingga diagnose budaya yang dihasilkan akan tepat.

Pengukuran dilakukan dengan mempertimbangkan budaya organisasi yang dikelola, tetapi memiliki batasan yang jelas. Oleh kerena itu, ketika menjawab pertanyaan perlu diingtakan organisasi dapat dipengaruhi oleh perubahan budaya. Metoe OCAI terdiri dari enam pertanyaan, setiap pertanyaan memiliki empat pilihan jawaban.

Pengukuran OCAI dibagi menjadi dua jenis pengukuran yaitu pengukuran saat ini dan yang diharapkan. Pengukuran OCAI untuk mengukur budaya organisasi yang ada dalam suatu organisasi. Budaya organisasi juga untuk mengukur budaya yang diharapkan seseorang untuk organisasinya. Pengukuran OCAI dapat memebantu organisasi melihat kondisi budaya organisasinya untuk mengambil tindakan perubahan setelah mengetahui kondisi budayanya.

Pada dasarnya, pengukuran OCAI dapat menentukan kecenderungan budaya organisasi suatu organisasi. sebuah organisasi memiliki tipe budaya organisasi Clan, Adokrasi, Marker, Hierarchy. Melalui pengukuran OCAI dapat menunjukan kondisi sekarang sesuai tipe budaya organisasi. Pengukuran OCAI juga dapat menunjukan budaya organisasi yang diharapkan oleh seseorang untuk organisasinya.

Langkah pertama yang dilakukan dalam pengukuran adalah membagi seratus poin antara keempat pilihan tergantung pada sejauh mana setiap pilihan mirip dengan organisasi. berikan jumlah yang lebih tinggi untuk menunjukan pilihan yang paling mirip dengan budaya organisasi yang ada. Misalnya, dalam satu pertanyaan, jika 1 ini sangat mirip dengan organisasi, pilihan 2 dan 3 yang agak mirip, dan 4 pilihan tidak mirip, untuk A diberi 40 poin, 30 poin untuk 2,20 poin untuk 3 dan 10 poin untuk 4. Pastikan totalnya 100 poin untuk setiap pertanyaan.

Dalam menentukan hasil akhir dari skor OCAI, dibutuhkan perhitungan aritmatika sederhana dengan menggunakan 2 kolom yaitu now coloumn dan preferred coloumn. Langkah pertama adalah menjumlahkan skor untuk 1 dari setiap tanggapan lalu dibagi enam, artinya menghitung skor rata-rata untuk pilihan 1 di kolom now coloumn. Lakukan hal ini untuk pertanyaan 2,3, dan 4. Langkah kedua menjumlahkan semua skor untuk 1 dari setiap tanggapan lalu dibagi enam, artinya menghitung rata-rata untuk pilihan 1 di dalam preferred coloumn. Lakukan hal ini untuk pertanyaan 2,3 dan 4.

\section{D.3.1. Analisis dan Pemodelan}

Dalam menganalisis budaya organisasi ini penulis menggunakan dua metode untuk rekomendasi yang lebih tepat yaitu Organizatioanl Culture Assesment Instrument (OCAI) dan Delone and Mclean. Adapun metode yang pertama ialah metode Organizatioanl Culture Assesment Instrument (OCAI) yang mana metode ini merupakan untuk mengukur kecenderungan tipe budaya organisasi, dan metode kedua ialah Delone and Mclean untuk mengukur kesuskesan sistem informasi.

\section{D.3.2. Hasil Pengukuran}

Tabel 8. Jawaban Rata-rata Responden

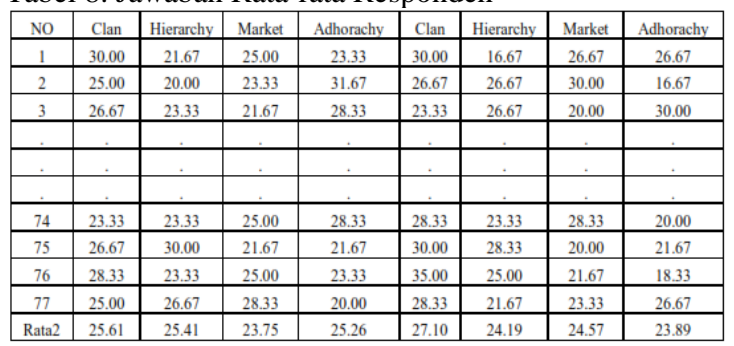

Hasil pengukuran ini di dapat dari rata-rata jawaban hasil kuisioner budaya organisasi yang di sisi oleh 77 orang..

Tabel 9. Peringkat Budaya Organisasi

\begin{tabular}{|l|c|c|c|c|}
\hline & Budaya Saat ini & Peringkat & Budaya Harapan & Peringkat \\
\hline Clan & 25.61 & $\mathbf{1}$ & 27.10 & $\mathbf{1}$ \\
\hline Hierarchy & 25.41 & 2 & 24.19 & 3 \\
\hline Market & 23.75 & 4 & 24.57 & 2 \\
\hline Adhorachy & 25.26 & 3 & 23.89 & 4 \\
\hline
\end{tabular}

Dari tabel 9 diatas dapat diketahui budaya yang paling tinggi nilainya baik sekarang maupun yang untuk diharapkan di masa yang akan datang. Budaya clan menjadi yang tertinggi saat ini dengan nilai 25.61 dan budaya yang diharapkan dimasa yang akan juga clan dengan nilai 27.10.

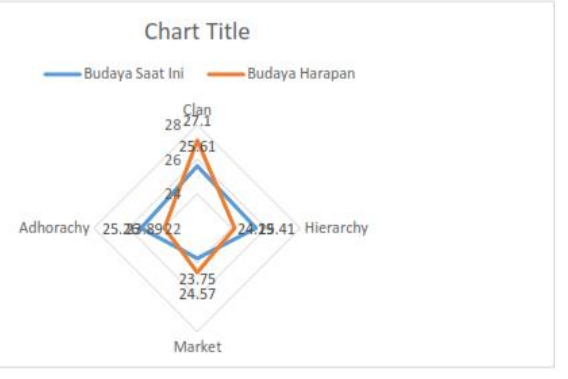

Gambar 8. Digram Radar Budaya

Dapat dilihat dari grafik pada gambar 4.4, budaya organisasi di UIN SUSKA Riau saat ini lebih cenderung ke kuadran Clan dengan poin yaitu 25.61. 
Sedangkan poin untuk hierarchy 25.41 , sedangkan untuk poin Adhorachy 25.26 dan 23.75 poin untuk point Clan. UIN SUSKA Riau mengambarkan budaya Clan focus pada kerja sama tim, komitmen dan bersifat kekeluargaan.

Harapan untuk kedepannya pada UIN SUSKA Riau mengingginkan budaya Clan atau menekankan focus pada kerja sama tim, komitmen dan bersifat kekeluargaan. Dapat dilihat dari grafik, untuk budaya organisasi yang diharapkan lebih tinggi untuk kuadran Hierarchy yaitu dengan jumlah 2.63 poin, untuk kuadran Market yaitu dengan jumlah 2.55 poin, untuk kuadran Adhorachy yaitu dengan jumlah 2.53 poin, dan untuk kuadran Clan yaitu dengan jumlah 2.22 poin.

\section{3.3. Pengolahan Data}

Teknik pengolahan data pada penelitian ini menggunakan metode SEM berbasis partial least Square (PLS). Pada analisis SEM-PLS biasanya terdiri dari dua sub model, yaitu model pengukuran atau outer model dan model structural atau inner model. Model pengukuran atau outer modelmenunjukan bagaimana variabel manifest atau observed varian mempresentasikan variabel laten untuk diukur. Sedangkan model structural menunjukan kekuatan estimasi antar variabel laten atau konstruk [22].

Model pengukuran (outer model) dan juga model structural (inner model) tersebut dianalisis melalui diagram jalur (path diagram) yang telah dirancang sebelumnya. Dari diagram jalur (path diagram) tersebut akan didapatkan nilai dari model pengukuran (outer model) dan juga nilai model structural (inner Model) dari estimasi yang dilakukan melalui program SmartPLS 3. Diagram jalur yang telah di rancang dapat dilihat dari gambar dibawah ini:

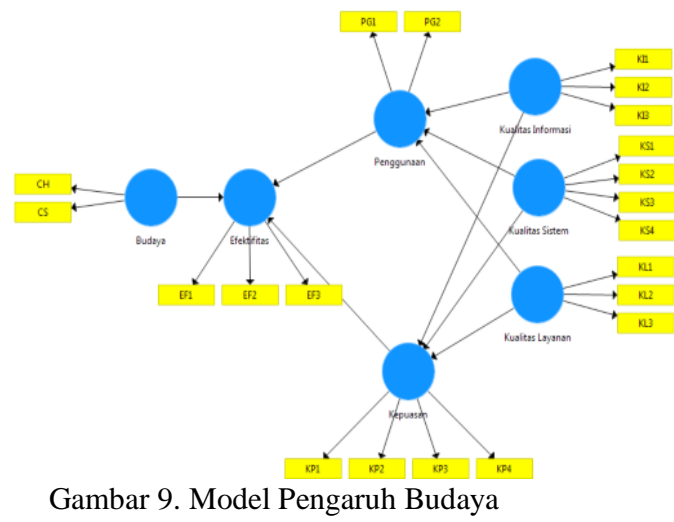

Adapun tahap pengolahan data dari diagram jalur (path diagram) yang telah dirancang melalui SmartPLS 3 dengan menggunakan metode SEMPLD adalah sebagai berikut:

Tabel 10. Keterangan Indikator

\begin{tabular}{|c|c|c|}
\hline Variabel & Indikator & Keterangan \\
\hline \multirow[t]{2}{*}{ Budaya } & $\mathrm{CH}$ & Clan budaya Harapan \\
\hline & $\mathrm{CS}$ & Clan budaya Sekarang \\
\hline \multirow[t]{3}{*}{ Efektifitas } & EFI & Efektifitas I \\
\hline & EF2 & Efektifitas 2 \\
\hline & EF3 & Efektifitas 3 \\
\hline \multirow[t]{2}{*}{ Penggunaan } & PGI & Penggunaan 1 \\
\hline & PG2 & Penggunaan 2 \\
\hline \multirow[t]{3}{*}{ Kepuasan } & KP1 & Kepuasan 1 \\
\hline & KP2 & Kepuasan 2 \\
\hline & KP3 & Kepuasan 3 \\
\hline & KP4 & Kepuasan 4 \\
\hline \multirow[t]{3}{*}{ Kualitas Informasi } & KII & Kualitas Informas I \\
\hline & KI2 & Kualitas Informas 2 \\
\hline & KI3 & Kualitas Informas 3 \\
\hline \multirow[t]{4}{*}{ Kualitas Sistem } & KSI & Kualitas Sistem I \\
\hline & KS2 & Kualitas Sistem 2 \\
\hline & $\overline{\mathrm{KS} 3}$ & Kualitas Sistem 3 \\
\hline & KS4 & Kualitas Sistem 4 \\
\hline \multirow[t]{3}{*}{ Kualitas Layanan } & KLI & Kualitas Layanan I \\
\hline & $\overline{\mathrm{KL} 2}$ & Kualitas Layanan 2 \\
\hline & KL3 & Kualitas Layanan 3 \\
\hline
\end{tabular}

Dari tabel 9 dapat dilihat indikator- indikator yang dipakai dalam penelitian, tipe budaya hanya diambil dua tipe yaitu Budaya Clan Saat Ini (CS) dan Budaya Clan Harapan $(\mathrm{CH})$. Data ini di dapat dari hasil pengolahan data Budaya Organisasi berdasarkan jawaban dari kuisioner.

\section{3.4. Evaluasi Outer Model (Model \\ Pengukuran)}

Evaluasi model pengukuran atau outer model dilakukan untuk menilai validitas dan reabilitas model. Ada dua mode untuk mengevaluasi onter model yaitu dengan mode A (refleksi) atau B (formatif). Outer model A (refleksi) dievaluasi melalui validitas convergent dan discriminat dari indicator pembentuk konsturk laten dan composite reability serta croncbach alpha untuk blok indicator (Chin, 1998 dikutip oleh Ghazali, 2016).

Outer model dengan mode B (formatif) dievaluasi dengan melihat signifikansi weight-nya. Sehingga uji aliditas dan reabilitas kosntruk tidak diperlukan. Untuk memperoleh signifikansi weight harus melalui prosedur resampling (jackknifing atau bootstrapping). Jika didapat nilai signifikansi weight T-statistics> 1.96 maka dapat disimpulkan bahwa indicator konstruk mode B (formatif) adalah valid.

Pada penelitian ini terdapat enam konstruk dengan indicator refleksi dan tidak ada kosntruk dengan indicator formatif. Konstruk-konstruk dengan indicator refleksi tersebut adalah System Qaulity, Service Quality, Organizational Culture, Use of System, User Satisfaction, dan Efektifitas. Pada tahap selanjutnya akan dijelaskan evaluasi 
onter model dari konstruk-konstruk penelitian sesuai dengan jenis indicator yang di tentukan.

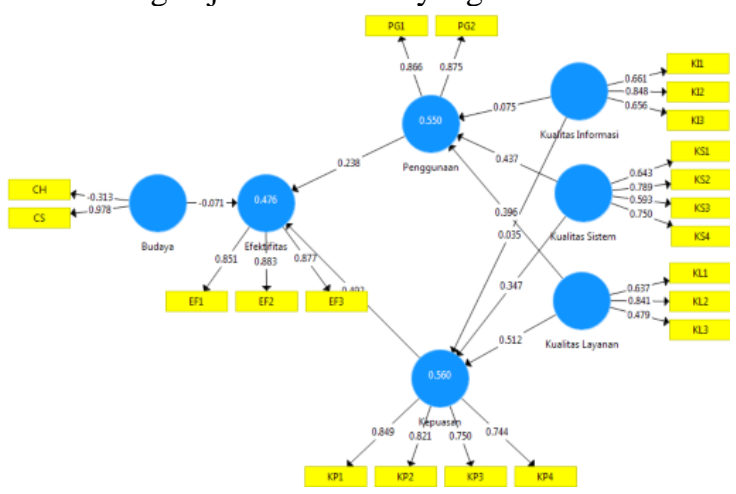

Gambar 10. Nilai Diagram jalur yang Telah Dirancang

\section{3.5. Konstruksi Ulang diagram Jalur (Path Diagram)}

Pada fase atau tahap ini Convergent Validity terdapat 7 kosntruk atau variabel refleksif yang telah di tentukan, terdapat 2 indikator yang tidak memenuhi kriteria penilaian convergent validity, yaitu memiliki nilai loading dibawah 0.5. Indikator yang tidak memenuhi standar nilai loading Corvergent Validity yaitu indicator KL3, dan $\mathrm{CH}$. Dimana nilai loading dari KL3 0.479 dan memiliki nilai loading $\mathrm{CH} 0.313$ harus dikeluarkan dari model kerena mimiliki nilai loading $<0.50 \quad$ [22]. Selanjutnya setelah hal tersebut dilakukan maka reestimasidapat dilakukan. Dibawah ini merupakan gambar model atau diagram jalur yang telah dimodifikasi.

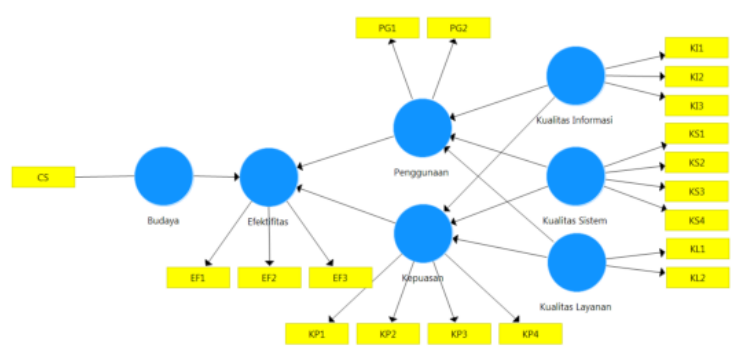

Gambar 11. Konstruksi Ulang Diagram Jalur

Dari diagram jalur yang telah dimodifikasi, hal selanjutnya yang harus dilakukan adalah mengestimasi ulang untuk melihat apakah nilai loading dari convergent validity telah memenuhi kreteria dari convergent validity. Dibawah ini merupakan hasil calculate atau estimasi ulang dari diagram jalur untuk mengetahui nilai loading dari masing-masing

indicator.

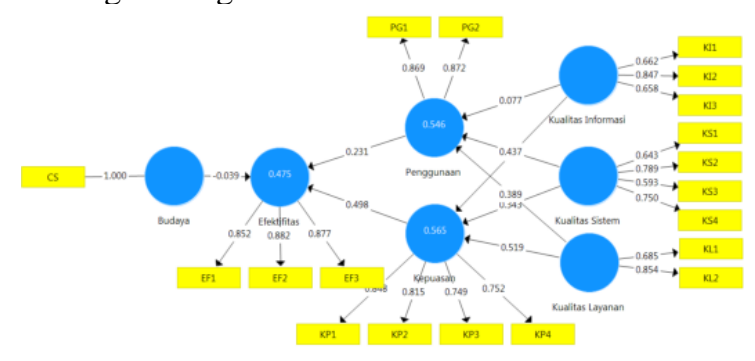

Gambar 12. Nilai Konstruksi Ulang Diagram Jalur

Hasil estimasi ulang terhadap model yang telah dimodifikasi, semua indicator dari masing-masing konstruk yang diteliti memiliki nilai loading $>0.50$. Pada model yang telah dimodifikasi ulang tersebut telah memenuhi kriteria dari pengukuran convergent validity. Oleh sebab itu, diagram jalur (path diagram) yang telah dimodifikasi memenuhi kriteria dan juga nilai loading dari masing-masing indicator telah memenuhi kriteria dari convergent validity dan dapat dilanjutkan untuk mengevaluasi model pengukuran (outer model) selanjutnya dan juga mengevaluasi model struktur (inner model) dari diagram jalur yang telah dimodifikasi. Dibawah ini merupakan hasil dari loading convergent validity dari model diagram jalur yang telah memenihi kriteria.

Tabel 11. Nilai Deskriminant Validity (Cross Loading)

\begin{tabular}{|l|c|c|c|c|c|c|c|}
\hline & Budaya & Efektifitas & Kepuasan & $\begin{array}{c}\text { Kualitas } \\
\text { Informasi }\end{array}$ & $\begin{array}{c}\text { Kualitas } \\
\text { Layanan }\end{array}$ & $\begin{array}{c}\text { ualitas } \\
\text { Sistem }\end{array}$ & Penggunaan \\
\hline CS & 1.000 & -0.080 & -0.055 & 0.024 & -0.076 & -0.017 & -0.060 \\
\hline EF1 & -0.033 & 0.852 & 0.612 & 0.546 & 0.550 & 0.378 & 0.540 \\
\hline EF2 & -0.133 & 0.882 & 0.516 & 0.216 & 0.456 & 0.323 & 0.507 \\
\hline EF3 & -0.050 & 0.877 & 0.611 & 0.401 & 0.592 & 0.325 & 0.509 \\
\hline KII & -0.106 & 0.354 & 0.260 & 0.662 & 0.276 & 0.201 & 0.257 \\
\hline KI2 & 0.106 & 0.390 & 0.319 & 0.847 & 0.370 & 0.293 & 0.379 \\
\hline K13 & 0.021 & 0.228 & 0.242 & 0.658 & 0.294 & 0.285 & 0.211 \\
\hline KL1 & -0.027 & 0.355 & 0.404 & 0.208 & 0.685 & 0.286 & 0.423 \\
\hline KL2 & -0.083 & 0.573 & 0.628 & 0.435 & 0.854 & 0.382 & 0.520 \\
\hline KP1 & -0.036 & 0.623 & 0.848 & 0.422 & 0.624 & 0.502 & 0.627 \\
\hline KP2 & -0.117 & 0.483 & 0.815 & 0.267 & 0.518 & 0.398 & 0.568 \\
\hline KP3 & -0.011 & 0.463 & 0.749 & 0.247 & 0.460 & 0.484 & 0.621 \\
\hline KP4 & -0.015 & 0.530 & 0.752 & 0.239 & 0.542 & 0.451 & 0.493 \\
\hline KS1 & -0.046 & 0.269 & 0.343 & 0.177 & 0.258 & 0.643 & 0.463 \\
\hline KS2 & -0.065 & 0.230 & 0.515 & 0.358 & 0.377 & 0.789 & 0.509 \\
\hline KS3 & 0.026 & 0.252 & 0.322 & 0.147 & 0.271 & 0.593 & 0.265 \\
\hline KS4 & 0.054 & 0.362 & 0.414 & 0.266 & 0.303 & 0.750 & 0.488 \\
\hline PG1 & -0.057 & 0.480 & 0.580 & 0.398 & 0.525 & 0.593 & 0.869 \\
\hline PG2 & -0.048 & 0.559 & 0.688 & 0.300 & 0.541 & 0.511 & 0.872 \\
\hline
\end{tabular}

Dari Tabel Cross Loading terdapat tujuh variabel refleksi, bisa dilihat bakwa korelasi 
konstruk dengan item pengukurannya lebih besar dari pada ukuran pada konstruk lainnya hal ini menunjukan bahwa konstruk laten memperdiksi ukuran pada blok mereka lebih tinggu dari pada blok lainnya. Dengan demikian dapat disimpulkan bahwa korelasi kosntruk dengan item pngukurannya (indicator) memiliki nilai discriminant validity yang baik. Cara lain untuk menilai descriminat validity selain dari nilai cross loading adalah dengan melihat nilai Average Variance Extracted (AVE). dipersyaratkan model yang baik jika AVE dapat ditunjukan pada tabel berikut:

Tabel 12. AVE

\begin{tabular}{|l|c|}
\hline & Rata-rata Varians Diekstrak (AVE) \\
\hline Budaya & 1.000 \\
\hline Efektifitas & 0.758 \\
\hline Kepuasan & 0.627 \\
\hline Kualitas Informasi & 0.529 \\
\hline Kualitas Layanan & 0.599 \\
\hline Kualitas Sistem & 0.488 \\
\hline Penggunaan & 0.758 \\
\hline
\end{tabular}

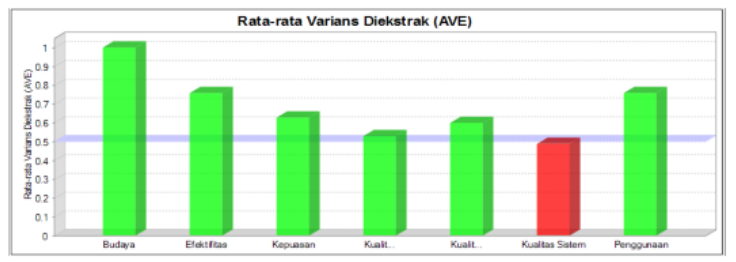

Gambar 13. AVE

Hasil output AVE diatas menunjukan masih ada nilai AVE dari setiap konstruk yang dibawah 0.50. dari hasil tersebut dapat dibuktikan nilai AVE menunjukan Deskriminat validity yang tidak baik.

\section{3.6. Composite Reability}

Selain uji validitas, pengukuran model juga dilakukan untuk menguji reabibilitas sautu konstruk. Uji reabilitas dilakukan untuk membuktikan akurasi, kosistensi dan ketepan instrument dalam pengukuran konstruk. Untuk mengukur reabilitas suatu konstruk dengan indicator formatif yaitu dengan composite reability dan cronbach alpha. Namun demikian penggunaan cronbach alpha untuk menguji relibialitas konstruk akan memberikan nilai yang lebih rendah (under estimate) sehingga lebih disarankan untuk menggunakan composite reliability dalam menguji reliabilitas konstruk. Penilaian yang biasa digunakan untuk mengguju reliabilitas konstruk dan dinyatakan reliable jika nilai composite reability diatas 0.70 dan untuk penelitian bersifat konfirmasi $0.60-0.70$ masih diterima untuk penelitian yang bersifat exploratory atau penyelidikan (Ghazali, 2016). Dibawah ini merupakan hasil dari pengujian composite reability dan cronbach alpha dari model penelitian.
Tabel 13. Rellabilitas Komposit

\begin{tabular}{|l|c|}
\hline & Rellabilitas Komposit \\
\hline Budaya & 1.000 \\
\hline Efektifitas & 0.904 \\
\hline Kepuasan & 0.870 \\
\hline Kualitas Informasi & 0.769 \\
\hline Kualitas Layanan & 0.747 \\
\hline Kualitas Sistem & 0.790 \\
\hline Penggunaan & 0.862 \\
\hline
\end{tabular}

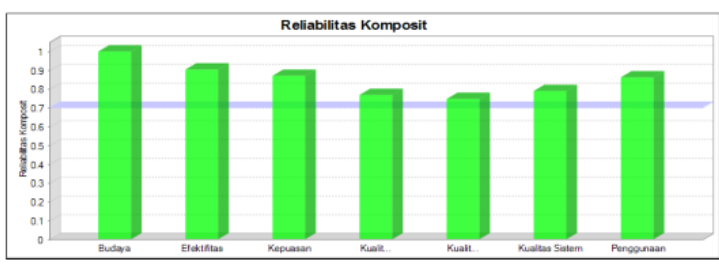

Gambar 14. Rellabilitas Komposit

Gambar 14 Relibilitas Komposit menunjukan nilai dari Relibilitas Komposit dari setiap variabel di atas 0.60 dan menunjukan reliabilitas dapat diterima dengan baik.

\section{3.7. Cronbach Alpha}

Tabel 14. Cronback Alpha

\begin{tabular}{|l|c|}
\hline & Cronbach's Alpha \\
\hline Budaya & 1.000 \\
\hline Efektifitas & 0.840 \\
\hline Kepuasan & 0.802 \\
\hline Kualitas Informasi & 0.553 \\
\hline Kualitas Layanan & 0.341 \\
\hline Kualitas Sistem & 0.650 \\
\hline Penggunaan & 0.681 \\
\hline
\end{tabular}

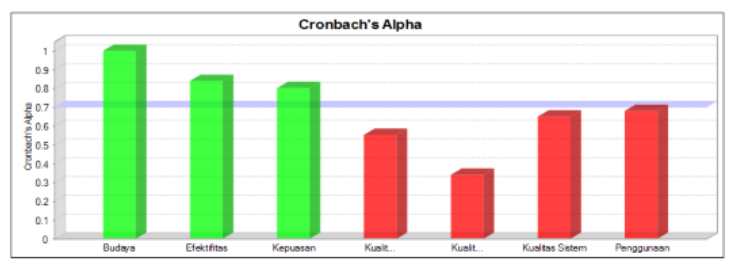

Gambar 15. Cronback Alpha

Gambar 15 Cronbach's Alpha menunjukan nilai dari Cronbach Alpha masih ada di bawah 0.60 yaitu Kualitas Layanan, Kualitas Informasi sehingga tidak valid dan untuk Cronbach Alpha diatas 0.60 yaitu Budaya, Efektifitas, Kepuasan, Kualitas sistem dan penggunaan.

\section{3.8. Evaluasi Model Struktural (inner Model)}

Evaluasi model structural atau inner model bertujuan untuk mempredisi hubungan antar variabel laten. Inner model dievaluasi dengan melihat besarnya persentase variance yang disajikann yaitu dengan melihat nilai R-Square untuk konstruk laten endogen [22]. Dalam menilai model structural dengan PLS, dimulai dengan melihat R-Square untuk setiap variabel laten 
endogen sebagai kekuatan prediksi dari model structural. Perubahan nilai R-Square dapat digunakan untuk menjelaskan pengaruh substantive atau yang paling pokok. Nilai R-Square $0.75,0.50$, 0.25 dapat disimpulkan bahwa model dikatakan kuat, moderate dan lemah [22]. Dibawah ini merupakan hasil penilaian hasil dari penelitian model structural dengan SmartPLS 3.

Tabel 15. R Square

\begin{tabular}{|l|c|}
\hline & R Square \\
\hline Efektifitas & 0.475 \\
\hline Kepuasan & 0.565 \\
\hline Penggunaan & 0.546 \\
\hline
\end{tabular}

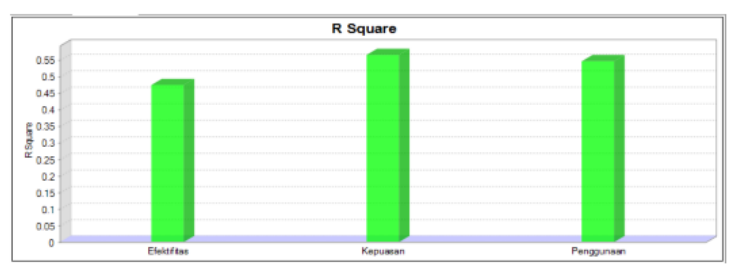

Gambar 16. R Square

Dari hasil diatas dapat dilihat nilai R-Square untuk variabel Efektifitas penggunaan sebesar 0.475 yang berarti termasuk dalam kategori lemah. Selanjutnya nilai R-Square untuk variabel Kepuasan sebesar 0.565 yang berarti termasuk dalam kategori moderate. Selanjutnya untuk nilai R-Square untuk variabel Penggunaan sebesar 0.546 yang berarti termasuk moderate. Uji kedua yang dapat dilakukan untuk menilai model structural adalah dengan melihat koefisiensi parameter dan nilai signifikansi $\mathrm{T}$ Statistik. Pada algorithm boostrapping report pilih coefficients.

Tabel 16. Path Coefficients

\begin{tabular}{|c|c|c|c|c|c|}
\hline & $\begin{array}{l}\text { Sampel } \\
\text { Asll (O) }\end{array}$ & \begin{tabular}{|c} 
Sample \\
Mean (M)
\end{tabular} & $\begin{array}{l}\text { Standar Deviasi } \\
\text { (STDEV) }\end{array}$ & $\begin{array}{l}\text { T Statistik (| } \\
\text { O/STDEV | }\end{array}$ & $\begin{array}{l}P \\
\text { Values }\end{array}$ \\
\hline Budaya $>$ Efektifitas & -0.039 & -0.035 & 0.081 & 0.477 & 0.633 \\
\hline $\begin{array}{l}\text { Kepuasan -> } \\
\text { Efektifitas }\end{array}$ & 0.498 & 0.507 & 0.121 & 4.132 & 0.000 \\
\hline $\begin{array}{l}\text { Kualittas Informasi -> } \\
\text { Kepuasan }\end{array}$ & 0.032 & 0.046 & 0.088 & 0.363 & 0.717 \\
\hline $\begin{array}{l}\text { Kualittas Informasi }-> \\
\text { Penggunaan }\end{array}$ & 0.077 & 0.084 & 0.095 & 0.811 & 0.418 \\
\hline $\begin{array}{l}\begin{array}{l}\text { Kualitas Layanan -> } \\
\text { Kepuasan }\end{array} \\
\end{array}$ & 0.519 & 0.506 & 0.087 & 5.933 & 0.000 \\
\hline $\begin{array}{l}\text { Kualitas Layanan }> \\
\text { Penggunaan } \\
\end{array}$ & 0.389 & 0.390 & 0.095 & 4.108 & 0.000 \\
\hline $\begin{array}{l}\begin{array}{l}\text { Kualltas Sistem -> } \\
\text { Kepuasan }\end{array} \\
\end{array}$ & 0.343 & 0.356 & 0.093 & 3.696 & 0.000 \\
\hline $\begin{array}{l}\text { Kualitas Sistem -> } \\
\text { Penggunaan }\end{array}$ & 0.437 & 0.442 & 0.084 & 5.208 & 0.000 \\
\hline $\begin{array}{l}\text { Penggunaan }>> \\
\text { Efektifitas }\end{array}$ & 0.231 & 0.227 & 0.123 & 1.884 & 0.060 \\
\hline
\end{tabular}

Dari hasil di atas terlihat bahwa terdapat lima konstruk yang memperngaruhi kerena niali $\mathrm{T}$ hitung $>$ T tabel yaitu Kepuasan mempengaruhi efektifitas, kualitas layanan mempengaruhi kepuasan, kualitas sistem mempengaruhi kepuasan, kualitas sistem mempengaruhi penggunaan, sedangkan konstruk yang tidak mempengaruhi kerena nilai $\mathrm{T}$ hitung $<\mathrm{T}$ tabel seperti kosntruk Budaya terhadap efektifitas, konstruk kualitas informasi terhadap kepuasan, konstruk kualitas informasi terhadap pengguna, konstruk penggunaan terhadap efektifias.

\section{3.9. Model Hipotesis yang diajukan}

Tabel 17. Hipotesis yang diajukan

\begin{tabular}{|c|c|l|}
\hline No & Hipotesis & \multicolumn{1}{|c|}{ Pernyataan Hipotesis } \\
\hline 1 & H1 & $\begin{array}{l}\text { Konstruk kualitas sistem } \\
\text { dipengaruhi penggunaan dalam } \\
\text { efektifitas sistem informasi }\end{array}$ \\
\hline 2 & H2 & $\begin{array}{l}\text { Konstruk kualitas sistem } \\
\text { dipengaruhi kepuasan dalam } \\
\text { efektifitas sistem informasi }\end{array}$ \\
\hline 3 & H3 & $\begin{array}{l}\text { Konstruk kualitas layanan } \\
\text { dipengaruhi penggunaan dalam } \\
\text { efektifitas sistem informasi }\end{array}$ \\
\hline 4 & H4 & $\begin{array}{l}\text { Konstruk kualitas layanan } \\
\text { dipengaruhi kepuasan dalam } \\
\text { efektifitas sistem informasi }\end{array}$ \\
\hline 5 & H5 & $\begin{array}{l}\text { Konstruk kualitas informasi } \\
\text { dipengaruhi penggunaan dalam } \\
\text { efektifitas sistem informasi }\end{array}$ \\
\hline 6 & H6 & $\begin{array}{l}\text { Konstruk kualitas informasi } \\
\text { dipengaruhi kepuasan dalam } \\
\text { efektifitas sistem informasi }\end{array}$ \\
\hline 7 & H7 & $\begin{array}{l}\text { Konstruk kepuasan dipengaruhi } \\
\text { konstruk efektifitas }\end{array}$ \\
\hline 8 & H8 & $\begin{array}{l}\text { Konstruk penggunaan } \\
\text { dipengaruhi konstruk efektifitas }\end{array}$ \\
\hline 9 & $\begin{array}{l}\text { Konstruk Efektifitas (EFEK) } \\
\text { dipengaruhi budaya dominan } \\
\text { organisasi dalam efektifitas } \\
\text { sistem informasi. }\end{array}$ \\
\hline
\end{tabular}

\section{3.10. Pengujian Hipotesis}

Dari tabel estimasi yang dilakukan memberikan informasi mengenai hubungan antar variable-variabel penelitian. Dasar yang dilakukan dalam menguji hipotesis adalah nilai yang terdapat pada output path coefficients. Gambar dibawah ini akan memberikan output estimasi untuk pengujian model structural.

Tabel 18. path coefficients

\begin{tabular}{|c|c|c|c|c|c|}
\hline & $\begin{array}{l}\begin{array}{l}\text { Sampel } \\
\text { Asll (0) }\end{array} \\
\end{array}$ & $\begin{array}{c}\text { Sample } \\
\text { Mean (M) }\end{array}$ & $\begin{array}{l}\text { Standar Deviasi } \\
\text { (STDEV) }\end{array}$ & $\begin{array}{l}\text { T Statistik ( } \\
\text { O/STDEV | }\end{array}$ & $\begin{array}{c}\text { P } \\
\text { Values } \\
\end{array}$ \\
\hline Budaya $->$ Efektifitas & -0.039 & -0.035 & 0.081 & 0.477 & 0.633 \\
\hline \begin{tabular}{ll|} 
Kepuasan & $\rightarrow$ \\
Efektifitas & $\rightarrow$ \\
\end{tabular} & 0.498 & 0.507 & 0.121 & 4.132 & 0.000 \\
\hline $\begin{array}{l}\text { Kualitas Informasi -> } \\
\text { Kepuasan }\end{array}$ & 0.032 & 0.046 & 0.088 & 0.363 & 0.717 \\
\hline $\begin{array}{l}\text { Kualltas Informasi >> } \\
\text { Penggunaan }\end{array}$ & 0.077 & 0.084 & 0.095 & 0.811 & 0.418 \\
\hline $\begin{array}{l}\text { Kualittas Layanan }> \\
\text { Kepuasan }\end{array}$ & 0.519 & 0.506 & 0.087 & 5.933 & 0.000 \\
\hline $\begin{array}{l}\text { Kualitas Layanan -> } \\
\text { Penggunaan }\end{array}$ & 0.389 & 0.390 & 0.095 & 4.108 & 0.000 \\
\hline $\begin{array}{l}\text { Kualitas Sistem } \\
\text { Kepuasan }\end{array}$ & 0.343 & 0.356 & 0.093 & 3.696 & 0.000 \\
\hline $\begin{array}{ll}\text { Kualittas Sistem } & > \\
\text { Penggunaan }\end{array}$ & 0.437 & 0.442 & 0.084 & 5.208 & 0.000 \\
\hline $\begin{array}{l}\text { Penggunaan } \\
\text { Efektfiftas }\end{array}$ & 0.231 & 0.227 & 0.123 & 1.884 & 0.060 \\
\hline
\end{tabular}

Dalam PLS pengujian secara statistic setiap hubungan yang dihipotesiskan dilakukan dengan mengunkan simulasi. Dalam hal ini dilakukan metode bootsrap terhadap sampel. Pengujian dalam boostrap juga dimaksud untuk meminimlakan masalah ketidak normalan data penelitian. Hasil 
pengujian dengan bootstrapping dari analisis PLS adalah sebagai berikut:

1. Pengujian Hipotesis 1 (kulaitas sistem terhadap penggunaan dalam penerapan efektifitas sistem informasi)

Hasil pengujian Hipotesis pertama menunjukan bahwa hubungan variabel Kualitas Sistem (KS) dengan Penggunaan (PG) menunjukan nilai koefisien jalur 0.437 dengan nilai $\mathrm{T}$ sebesar 5.208. Nilai tersebut lebih besar dari T tabel (1.96). Hasil ini berarti bahwa KS memiliki hubungan yang signifikan terhadap PG yang berarti sesuai dengan hipotesis pertama dimana KS mempengaruhi PG dalam mengunakan kualitas sistem. Hal ini berarti Hipotesis 1 Diterima.

2. Pengujian Hipotesis 2 (kualitas sistem terhadap kepuasan dalam penerapan sistem informasi) Hasil pengujian Hipotesis kedua menunjukan bahwa hubungan variabel Kualitas Sistem (KS) dengan Kepuasan (KP) menunjukan nilai koefisien jalur 0.343 dengan nilai $\mathrm{T}$ sebesar 3.696. Nilai tersebut lebih besar dari $\mathrm{T}$ tabel (1.96). Hasil ini berarti bahwa KS memiliki hubungan yang signifikan terhadap KP yang berarti sesuai dengan hipotesis kedua dimana KS mempengaruhi KP dalam mengunakan kualitas sistem. Hal ini berarti Hipotesis 2 Diterima.

3. Pengujian Hipotesis 3 (kualitas layanan terhadap penggunaan dalam penerapan sistem informasi)

Hasil pengujian Hipotesis ketiga menunjukan bahwa hubungan variabel Kualitas Layanan (KL) dengan Penggunaan (PG) menunjukan nilai koefisien jalur 0.389 dengan nilai T sebesar 4.108. Nilai tersebut lebih besar dari T tabel (1.96). Hasil ini berarti bahwa KL memiliki hubungan yang signifikan terhadap PG yang berarti sesuai dengan hipotesis ketiga dimana KL mempengaruhi PG dalam mengunakan kualitas layanan. Hal ini berarti Hipotesis 3 Diterima.

4. Pengujian Hipotesis 4 (kualitas layanan terhadap kepuasan dalam penerapan sistem informasi)

Hasil pengujian Hipotesis keemapat menunjukan bahwa hubungan variabel Kualitas Layanan (KL) dengan Kepuasan (KP) menunjukan nilai koefisien jalur 0.519 dengan nilai $\mathrm{T}$ sebesar 5.933. Nilai tersebut lebih besar dari T tabel (1.96). Hasil ini berarti bahwa KL memiliki hubungan yang signifikan terhadap KP yang berarti sesuai dengan hipotesis keempat dimana KL mempengaruhi KP dalam mengunakan kualitas layanan. Hal ini berarti Hipotesis 4 Diterima.

5. Pengujian Hipotesis 5 (kualitas informasi terhadap penggunaan dalam penerapan sistem informasi)
Hasil pengujian Hipotesis kelima menunjukan bahwa hubungan variabel Kualitas Informasi (KI) dengan Penggunaan (PG) menunjukan nilai koefisien jalur 0.077 dengan nilai $\mathrm{T}$ sebesar 0.811 . Nilai tersebut lebih kecil dari T tabel (1.96). Hasil ini berarti bahwa KI memiliki hubungan yang tidak signifikan terhadap KP yang berarti tidak sesuai dengan hipotesis kelima dimana KL mempengaruhi KP dalam mengunakan kualitas Informasi. Hal ini berarti Hipotesis 5 Ditolak.

6. Pengujian Hipotesis 6 (kualitas informasi terhadap kepuasan dalam penerapan sistem informasi)

Hasil pengujian Hipotesis keenam menunjukan bahwa hubungan variabel Kualitas Informasi (KI) dengan Kepuasan (KP) menunjukan nilai koefisien jalur 0.032 dengan nilai $\mathrm{T}$ sebesar 0.363 . Nilai tersebut lebih kecil dari $\mathrm{T}$ tabel (1.96). Hasil ini berarti bahwa KI memiliki hubungan yang tidak signifikan terhadap KP yang berarti tidak sesuai dengan hipotesis keenam dimana KI mempengaruhi KP dalam mengunakan kualitas Informasi. Hal ini berarti Hipotesis 6 Ditolak.

7. Pengujian Hipotesis 7 (kupuasan terhadap efektifitas dalam penerpaan sistem informasi)

Hasil pengujian Hipotesis ketujuh menunjukan bahwa hubungan variabel Kepuasan (KP) dengan Efektifitas (EF) menunjukan nilai koefisien jalur 0.498 dengan nilai $\mathrm{T}$ sebesar 4.132. Nilai tersebut lebih besar dari $\mathrm{T}$ tabel (1.96). Hasil ini berarti bahwa KP memiliki hubungan yang signifikan terhadap EF yang berarti sesuai dengan hipotesis ketujuh dimana KP mempengaruhi EF dalam mengunakan kepuasan. Hal ini berarti Hipotesis 7 Diterima.

8. Pengujian Hipotesis 8 (penggunaan terhadap efektifitas dalam penerapan sistem informasi)

Hasil pengujian Hipotesis kedelapan menunjukan bahwa hubungan variabel Penggunaa (PG) dengan Efektifitas (EF) menunjukan nilai koefisien jalur 0.231 dengan nilai $\mathrm{T}$ sebesar 1.884. Nilai tersebut lebih kecil dari T tabel (1.96). Hasil ini berarti bahwa PG memiliki hubungan yang tidak signifikan terhadap EF yang berarti tidak sesuai dengan hipotesis delapan dimana PG mempengaruhi EF dalam mengunakan penggunaan. Hal ini berarti Hipotesis 8 Ditolak.

9. Pengujian Hipotesis 9 (budaya terhadap efektifitas dalam penerapan sistem informasi)

Hasil pengujian Hipotesis kesembilan menunjukan bahwa hubungan variabel Budaya (BD) dengan Efektifitas (EF) menunjukan nilai koefisien jalur -0.039 dengan nilai $\mathrm{T}$ sebesar 0.477 . Nilai tersebut lebih kecil dari $\mathrm{T}$ tabel (1.96). Hasil ini berarti bahwa BD memiliki hubungan yang tidak signifikan terhadap EF yang berarti tidak sesuai dengan hipotesis kesembilan dimana Budaya 
mempengaruhi EF dalam mengunakan budaya. Hal ini berarti Hipotesis 9 Ditolak.

Tabel 19. Hasil Uji Hipotesis

\begin{tabular}{|c|c|c|c|l|}
\hline Hipotesis & Konstruk & T- Table & T- Statistics & Hasil \\
\hline I & KS $>$ PG & 0.437 & 5.208 & Hipotesis 1 Diterima \\
\hline 2 & $\mathrm{KS}>\mathrm{KP}$ & 0.343 & 3.696 & Hipotesis 2 Diterima \\
\hline 3 & $\mathrm{KL}>\mathrm{PG}$ & 0.389 & 4.108 & Hipotesis 3 Diterima \\
\hline 4 & $\mathrm{KL}>\mathrm{KP}$ & 0.519 & 5.933 & Hipotesis 4 Diterima \\
\hline 5 & $\mathrm{KI}>\mathrm{PG}$ & 0.077 & 0.811 & Hipotesis 5 Ditolak \\
\hline 6 & $\mathrm{KI}>\mathrm{KP}$ & 0.032 & 0.363 & Hipotesis 6 Ditolak \\
\hline 7 & $\mathrm{KP}>\mathrm{EF}$ & 0.498 & 4.132 & Hipotesis 7 Diterima \\
\hline 8 & $\mathrm{PG}>\mathrm{EF}$ & 0.231 & 1.884 & Hipotesis 8 Ditolak \\
\hline 9 & $\mathrm{BD}>\mathrm{EF}$ & -0.039 & 0.477 & Hipotesis 9 Ditolak \\
\hline
\end{tabular}

Dari keterangan tabel hasil uji hipotesis dinyatakan 5 hipotesis yang dapat diterima yaitu KS -> PG, KS -> KP, KL -> PG, KL -> KP, KP -> EF yang mana nilai $\mathrm{T}$ - Statistik di atas 1.96 . Hipotesis yang di nyatakan ditolak ada 4 yaitu KI -> PG, KI $>\mathrm{KP}, \mathrm{PG}->\mathrm{EF}$, dan $\mathrm{BD}$-> EF yang mana nilai $\mathrm{T}$ Statistik di bawah 1.96.

\section{D.3.11. Model Pengaruh Budaya Organisasi}

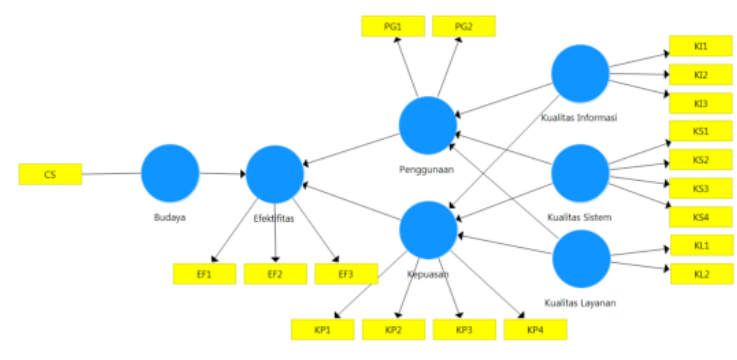

Gambar 17. Model Pengaruh Budaya Organisasi

\section{D.3.12. Pembahasan dan Hasil}

Pengelolaan data serta pengujian yang telah dilakukan untuk mengetahui pengaruh budaya oganisasi terhadap efektifitas iRaise dengan menggunakan Delone and Mclean, hasil data yang telah diolah adalah sebagai berikut:

1. Budaya Organisasi

Penilaian badaya organisasi menggunakan Culture ValueFramework (CVF) dengan menggunakan 4 Indikator yaitu Clan, Adhorachy, Hierarchy dan Market. Dengan penilaian ini lalu dicari nilai tertinggi dari masing-masing jawaban sehingga di dapat budaya organisasi sekarang dan budaya organissi yang akan datang. budaya yang di dapat untuk saat ini yaitu Budaya Clan dengan nilai 25.61 dan untuk budaya yang diharapkan juga budaya Clan dengan nilai 27.10. budaya Clan lebih memfokuskan pada kinerja tim, komitmen dan bersifat kekeluargaan.

Hal ini menyatakan bahwa budaya yang sedang berjalan di UIN SUSKA Riau seperti keluarga besar yang mana saling berbagi satu sama lain serta mengembangkan kemampuan, kepercayaan yang tinggi, keterbukaan dan selalu berpartisipasi. Serta untuk budaya organisasi harapan UIN SUSKA Riau mengharapkan adanya kerjasama tim (team work), kesepakatan dan berpartisipasi seluruh mahasiswa.

2. Kualitas Sistem Informasi Terhadap Penggunaan dalam Penerapan Efektifitas Sistem Informasi

Hasil pengujian Hipotesis pertama menunjukan bahwa hubungan variabel Kualitas Sistem (KS) dengan Penggunaan (PG) menunjukan nilai koefisien jalur 0.437 dengan nilai $\mathrm{T}$ sebesar 5.208. Nilai tersebut lebih besar dari T tabel (1.96). Hasil ini berarti bahwa KS memiliki hubungan yang signifikan terhadap PG yang berarti sesuai dengan hipotesis pertama. Pengaruh positif tersebut di sebabkan kerena iRaise berjalan dengan penggunaan yang baik serta tersedianya akses yang dapat dilakukan selama 24 Jam.

3. Kualitas Sistem Terhadap Kepuasan dalam Penerapan Sistem Informasi

Hasil pengujian Hipotesis kedua menunjukan bahwa hubungan variabel Kualitas Sistem (KS) dengan Kepuasan (KP) menunjukan nilai koefisien jalur 0.343 dengan nilai $\mathrm{T}$ sebesar 3.696. Nilai tersebut lebih besar dari $\mathrm{T}$ tabel (1.96). Hasil ini berarti bahwa KS memiliki hubungan yang signifikan terhadap KP yang berarti sesuai dengan hipotesis kedua. Pengaruh positif tersebut di sebabkan kerena sistem informasi dengan pengunaan yang baik serta menyukai dengan tampilan iRaise yang ada saat ini.

4. Kualitas Layanan Terhadap Penggunaan dalam Penerapan Sistem Informasi

Hasil pengujian Hipotesis ketiga menunjukan bahwa hubungan variabel Kualitas Layanan (KL) dengan Penggunaan (PG) menunjukan nilai koefisien jalur 0.389 dengan nilai T sebesar 4.108. Nilai tersebut lebih besar dari T tabel (1.96). Hasil ini berarti bahwa KL memiliki hubungan yang signifikan terhadap PG yang berarti sesuai dengan hipotesis ketiga. Pengaruh positif ini di sebabkan kerena iRaise yang digunakan memberi pelayanan yang baik serta bisa diakses selama 24 jam.

5. Kualitas Layanan Terhadap Kepuasan dalam Penerapan Sistem Informasi

Hasil pengujian Hipotesis keemapat menunjukan bahwa hubungan variabel Kualitas Layanan (KL) dengan Kepuasan (KP) menunjukan nilai koefisien jalur 0.519 dengan nilai $\mathrm{T}$ sebesar 5.933. Nilai tersebut lebih besar dari T tabel (1.96). Hasil ini berarti bahwa KL memiliki hubungan yang signifikan terhadap KP yang berarti sesuai dengan hipotesis keempat. Pengaruh positif ini disebabkan kerena iRiase yang digunakan memberikan pelayana yang baik serta bagusnya tampilan pada iRaise saat ini.

6. Kualitas Informasi Terhadap Penggunaan dalam Penerapan Sistem Informasi

Hasil pengujian Hipotesis kelima menunjukan bahwa hubungan variabel Kualitas Informasi (KI) 
dengan Penggunaan (PG) menunjukan nilai koefisien jalur 0.077 dengan nilai T sebesar 0.811 . Nilai tersebut lebih kecil dari T tabel (1.96). Hasil ini berarti bahwa KI memiliki hubungan yang tidak signifikan terhadap KP yang berarti tidak sesuai dengan hipotesis kelima. Pengaruh negative Kerena menurut mahasiswa masih tidak efektif dalam menggunakan iRaise dan sistem belum cukup kuat untuk digunakan.

7. Kualitas Informasi Terhadap Kepuasan dalam Penerapan Sistem Informasi

Hasil pengujian Hipotesis keenam menunjukan bahwa hubungan variabel Kualitas Informasi (KI) dengan Kepuasan (KP) menunjukan nilai koefisien jalur 0.032 dengan nilai $\mathrm{T}$ sebesar 0.363 . Nilai tersebut lebih kecil dari $\mathrm{T}$ tabel (1.96). Hasil ini berarti bahwa KI memiliki hubungan yang tidak signifikan terhadap KP yang berarti tidak sesuai dengan hipotesis keenam. Pengaruh negative disebabkan kurang efektifnya dalam menggunakan iRaise serta konten di iRaise saat ini tidak ada perubahan dari tahun ketahun.

\section{Kepuasan Terhadap Efektifitas dalam} Penerapan Sistem Informasi

Hasil pengujian Hipotesis ketujuh menunjukan bahwa hubungan variabel Kepuasan (KP) dengan Efektifitas (EF) menunjukan nilai koefisien jalur 0.498 dengan nilai $\mathrm{T}$ sebesar 4.132. Nilai tersebut lebih besar dari $\mathrm{T}$ tabel (1.96). Hasil ini berarti bahwa KP memiliki hubungan yang signifikan terhadap EF yang berarti sesuai dengan hipotesis ketujuh. Pengaruh positif ini di sebabkan mahasiswa menyukai tampilan iRaise saat ini serta dengan iRaise pngisian KRS bisa lebih mudah yang memberikan hasil yang baik.

9. Penggunaan Terhadap Efektifitas dalam Penerapan Sistem Informasi

Hasil pengujian Hipotesis kedelapan menunjukan bahwa hubungan variabel Penggunaa (PG) dengan Efektifitas (EF) menunjukan nilai koefisien jalur 0.231 dengan nilai $\mathrm{T}$ sebesar 1.884. Nilai tersebut lebih kecil dari T tabel (1.96). Hasil ini berarti bahwa PG memiliki hubungan yang tidak signifikan terhadap EF yang berarti tidak sesuai dengan hipotesis delapan. Pengaruh negative ini disebabkan kerena iRaise belum cukup efektif digunakan serta iRaise sering bermasalah.

10. Budaya Terhadap Efektifitas dalam Penerapan Sistem Informasi

Hasil pengujian Hipotesis kesembilan menunjukan bahwa hubungan variabel Budaya (BD) dengan Efektifitas (EF) menunjukan nilai koefisien jalur 0.039 dengan nilai $\mathrm{T}$ sebesar 0.477 . Nilai tersebut lebih kecil dari T tabel (1.96). Hasil ini berarti bahwa BD memiliki hubungan yang tidak signifikan terhadap EF yang berarti tidak sesuai dengan hipotesis kesembilan. Pengaruh negative disebabkan kerena budaya Clan lebih memfokuskan pada kinerja tim, komitmen dan bersifat kekeluargaan kerena hal itu apabila salah satu anggota tim berhalangan maka pekerjaan tidak bisa diteruskan dan hal itu menyebabkan produktifitas yang kurang baik dan membuat pekeraan menjadi terlambat.

\section{E. PENUTUP \\ E. 1. Kesimpulan}

Berdasarkan hasil analisa data pada bab sebelumnya, diperoleh beberapa kesimpulan, yaitu:

1. Budaya Organiasai yang dominan saat ini di UIN SUSKA Riau adalah budaya Clan yaitu sebesar 25.61 lebih tinggi dari pada budaya yang lainnya, budaya clan lebih menekankan focus personal, seperti sebuah kelaurga besar dimana orangorang saling berbagi satu sama lain serta kemapuan SDM, Kepercayaan yang tinggi, keterbukaan dan partisipan. Sedangkan untuk budaya harapan UIN SUSKA Riau kedepannya juga budaya Clan 27.10 dengan penambahan yang diinginkan adanya kerja sama tim.

2. Budaya Organisasi tidak berpengaruh terhadap efektifitas sistem informasi iRaise dengan nilai $\mathrm{T}$ Statistik $<1.96$, kerena budaya lebih memfokuskan pada kinerja tim, komitmen dan bersifat kekeluargaan kerena hal itu apabila salah satu anggota tim berhalangan maka pekerjaan tidak bisa diteruskan dan hal itu menyebabkan produktifitas yang kurang baik dan membuat pekeraan menjadi terlambat.

\section{F. DAFTAR PUSTAKA}

[1] Megawati At All. 2015. Evaluasi Budaya Organisasi Dalam Penerapan Teknologi Informasi Menggunakan Organizational Culture Assessment Instrument (OCAI) Pada PT. Perkebunan Nusantara V Pekanbaru. Pekanbaru: UIN SUSKA Riau.

[2] Suwiprabayanti Putra. 2017. Analisis Budaya Organisasi Menggunakan Model OCAI (Organizational Culture Assessment Instrument) Pada Universitas XYZ. Bali: STIKOM Bali.

[3] Laudon, Kenneth C., \& Jane, P. Laudon. 2010. Manajemen Information System :Managing The Digital Firm. New Jersey: Prentice-Hall.

[4] Trisnaningsih Tri. 2007. Independensi Auditor Dan Komitmen Organisasi Sebagai Mediasi Pengaruh Pemahaman Good Governance, Gaya Kepemimpinan Dan Budaya Organisasi Terhadap Kinerja Auditor. Makassar: Universitas Pembangunan Nasional (Upn) "Veteran" Jawa Timur.

[5] Gibson. L \& Ivancevich. 2001. Organizations (Behavior, Structure And Process), Richard D. Irwin, Inc. Terjemah PT. Binarupa Aksara, Jakarta. 
[6] Badan Pusat Statistik Provinsi Riau. 2014.

[7] Robert Lamb At All. 2003. Reconceptualizing User And Social Actors In Information System Research. MIS Quarterly: University Of Minnesota.

[8] Cholid Fauzi. 2015. Pengaruh Budaya Organisasi Terhadap Efektifitas Sistem Informasi. Bandung: Sekolah Tinggi Sains Dan Teknologi Informasi.

[9] Murahartawaty. 2010. Analisa Pengaruh Budaya Organisasi Terhdap Implementasi Sistem Informasi (Studi Kasus : Web Portal Institut Teknologi Bandung). Bandung: ITB.

[10] Geer Hofstede. 1984. Cultural Dimensions In Management And Planning.

[11] Report Organizational Culture Assessment Instrument Company Date. (2012).

[12] Wahyuningsih Tri Thoyyibah. 2015. Analisis Pemetaan Budaya Organisasi Menggunakan Organizational Culture Assessment Instrument (Ocai) Pada Universitas Islam Negeri (Uin) Walisongo Semarang. Semarang: Universitas Islam Negeri (Uin) Walisongo Semarang.

[13] Muhammad Umartias, Dkk. 2014. Pemetaan Budaya Organisasi Menggunakan Organizational Culture Assessment Instrument (Ocai) Pada Pt Kereta Api Indonesia Daerah Operasional 4 Semarang.

[14] Kusdi. 2011. Budaya Organisasi : Teori, Penelitian, Dan Praktik. Jakarta: Salemba Empat.

[15] Delone, W. H., \& Mclean, E. R. 2003. The Delone And Mclean Model Of Information Systems Success : A Ten-Year Update. Journal Of Management Information Systems / Spring, 19(4), 9 - 30.

[16] Hevner, A. R., March, S. T., \& Park, J. 2004. Design Science In Information System Research. MIS Quarterly Vol. 28 No.1, 75105.

[17] Sugiyono. 2011. Metode Penelitian Kuantitatif, Kualitatif Dan R\&D. Bandung: Afabeta.

[18] Rutoto, Sabar. 2007. Pengantar Metedologi Penelitian. FKIP: Universitas Muria Kudus.

[19] Rahayu Siti Kurnia At All. 2011. Analisis Budaya Organisasi Pada Pengembangan Sistem Informasi Di Unikom. Universitas Komputer Indonesia.

[20] Jogiyanto, H.M. 2009. Konsep Dan Aplikasi PLS (Partial Least Square) Untuk Penelitian Empiris. Yogyakarta: BPFE.

[21] Hartono Abdillah, W., Dan J. Hartono. 2015. Partial Least Square (PLS). Penerbit Andi. Yogyakarta.

[22] Ghazali. 2014. Partial Least Squares Konsep, Teknki Dan Aplikasi Menggunakan Program Smartpls 3.0 